
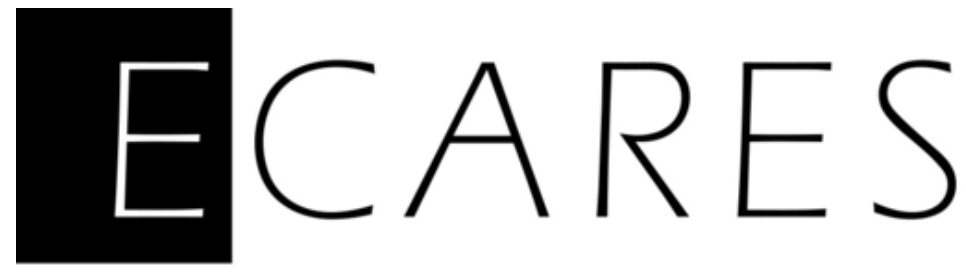

\title{
The Big Sell: Privatizing East Germany's Economy
}

\author{
Lukas Mergele \\ University of Munich \\ Moritz Hennicke \\ Université libre de Bruxelles \\ Moritz Lubczyk \\ University of Zurich
}

September 2020 


\title{
THE BIG SELL: PRIVATIZING EAST GERMANY'S ECONOMY
}

\author{
Lukas Mergele $\circledast$ Moritz Hennicke $\circledast$ Moritz Lubczyk
}

\begin{abstract}
The end of communism in the 1990s probably is the most fundamental restructuring of institutions witnessed in recent history. At its core was the large-scale redistribution of previously state-owned companies. We construct a unique firm-level dataset to study this redistribution in East Germany where the entire state-owned economy was either privatized or liquidated within less than five years. We examine whether the privatization authority followed its mandate to privatize competitive firms using initial labor productivity to indicate firms' competitiveness. Our results highlight that firms with higher baseline productivity are more likely to be privatized, yield higher sales prices, are more often acquired by West German investors, and are more likely to remain in business even 20 years after leaving public ownership. The privatization agency plausibly contributed to these outcomes by rating and prioritizing productive firms.
\end{abstract}

JEL-Classification: D24, G38, H11, L33, P31

Keywords: Privatization, labor productivity, German reunification

Date: This version: September 11, 2020.

Affiliations: Mergele (corresponding author): ifo Institute and University of Munich, mergele@ifo.de. Hennicke: Université libre de Bruxelles and Université de Cergy-Pontoise. Lubczyk: ZEW - Centre for European Economic Research Mannheim and University of Zurich. (1) indicates that the order of authors is randomized.

Acknowledgments: We thank Maja Adena, Loren Brandt, Michael Burda, Davide Cantoni, Micael Castanheira, Mirco Draca, Bernd Fitzenberger, Guido Friebel, Roger Gordon, Rajshri Jayaraman, Ulrich Kaiser, Nicola Mastrorocco, Steffen Müller, Krisztina Orban, Albrecht Ritschl, Gérard Roland, Moritz Schularick, Alexandra Spitz-Oener, Romain Wacziarg, Fabian Waldinger, and Ekaterina Zhuravskaya for valuable discussions and suggestions. We are grateful for comments received by seminar participants in Berlin, Brussels, Halle, Mannheim, Munich, Zurich, the Verein für Socialpolitik annual conference (Leipzig), the Institut für Zeitgeschichte Treuhand Workshop (Berlin), and the Spring Meeting of Young Economists (Brussels). Marcus Böick, Katja Fuder, Wolf-Rüdiger Knoll, Maria von Löwenich and André Steiner provided valuable guidance on archival data and the historical background. We thank Harald Hau for sharing the Treuhand contract data with us. Maxime Amadio, Djordje Dotlic and Oliver Wach provided excellent research assistance. Lukas Mergele acknowledges funding through DFG RTG 1659, Fritz-Thyssen Foundation, and the Joachim Herz Foundation. 


\section{Introduction}

The end of communism in the 1990s heralded what probably is the most fundamental restructuring of economic and political institutions in recent history. The Soviet Union and its allies abandoned central planning and one-party rule in favor of market economy and liberal democracy. The former German Democratic Republic (GDR), or East Germany, was unique as it adopted these institutions faster than any other transition country. This was because German reunification implied that the East inherited the economic and political institutions of its Western neighbor. Consequently, Germany has been seen as a testing ground for whether liberal democracy, competitive markets, and private ownership can achieve convergence in prosperity. In this context, the redistribution of state-held assets became one of the crucial questions for economic policy, both in East Germany and in other transition states.

This study focuses on the privatization program pursued by East Germany following the fall of the Berlin Wall in 1989; it is considered one of the most extensive privatization programs ever launched. Within less than five years, the entire state-owned economy underpinning the former German Democratic Republic was privatized or liquidated. ${ }^{1}$ There was no blueprint for this task that was led by a public privatization agency, the Treuhand ("trust agency", abbreviated THA). The Treuhand's decisions were accompanied by furious protests, including hunger strikes and the assassination of the Treuhand's president in 1991. Thirty years later, 93 per cent of East Germans think that the effects of the Treuhand decisions can still be felt while only ten per cent agree that they can be considered a success (mdr, 2020). Public dissatisfaction is echoed by Germany's populist left and extreme right parties, which advocate for a parliamentary inquiry into the Treuhand privatizations. ${ }^{2}$

In this paper, we present the first comprehensive study of the Treuhand's privatization activities and their economic short- and long-term consequences. To this end, we derive stylized facts from a unique firm dataset based on previously unavailable sources. We construct this dataset by combining administrative data from the privatization agency and historical archives with micro-level firm surveys and long-term ownership panels. We examine the Treuhand's major goal, which was to restore competitive companies and privatize them as quickly as possible. We assess the privatization agency's actions by examining firms' initial labor productivity as a simple indicator of firms' competitiveness and evaluate how privatization outcomes vary across the productivity distribution.

\footnotetext{
${ }^{1}$ With few predefined exceptions, firms were transferred to municipalities or previously expropriated owners. See Section 2 for details.

${ }^{2}$ Björn Höcke, Alternative for Germany (May 1, 2019): "The impoverishment and homeland destruction here with us has a name. That name is Treuhand." Dietmar Bartsch, The Left (June 27, 2019): "The Treuhandanstalt privatized one hundred times more companies in one year than Maggie Thatcher privatized in ten years. [...] The Treuhand deindustrialized on a large scale and thus set back the East to this day." (Adler, 2019; von Lieben, 2019).
} 
These outcomes include the selection of firms to be privatized, the speed of privatization, and the privatization contracts' key components, most notably sales prices. Finally, we examine how postprivatization outcomes vary depending on the efficiency of privatization candidates. In particular, we analyze how initial firm-level productivity under state ownership shaped the new ownership allocation and long-term firm survival up to twenty years following privatization.

East Germany is an attractive research context for at least four reasons. First, the privatization program provides a valuable comparative perspective. East Germany's transition from socialism to capitalism began quickly and provided a model that gained widespread recognition beyond Central and Eastern Europe. Second, the program was on an enormous scale. The Treuhand owned the entire population of industrial firms from the former German Democratic Republic (GDR) and was commonly referred to as "the world's largest holding". Third, the privatization program was not anticipated as German reunification came as a surprise. ${ }^{3}$ As such, it seems unlikely that unobserved anticipation effects would affect our results. Fourth, the political direction of the program was clear. The governing coalition of conservatives and liberals enjoyed broad support through the first common federal election in reunified Germany. The federal government ruled out continued state ownership, and set a clear endpoint for the program at an early stage. Jointly, these characteristics make East German mass privatizations an unusually rich and clear setting.

To construct our dataset, our starting point is an administrative register of all Treuhand firms and their final privatization outcome. We then draw upon firm surveys to construct labor productivity indicators at the beginning of the program, as these are the most common measures of single-factor productivity (Syverson, 2011). From newly accessible data at the German National Archives, we digitize firm rating scores used internally by the Treuhand to open the black box of internal prioritization within the privatization agency. Moreover, we retrieve privatization contract data on sales prices as well as employment and investment pledges made by investors. Finally, we exploit private register data that enables the tracing of privatized firms under their new ownership for more than 20 years. This way, we can describe the impact of post-reunification privatizations right up to the most recent past. Our dataset is unique when it comes to exploiting internal firm rating scores of a privatization authority, observing privatization prices (Lopez-de Silanes (1997) is another exception here), and studying privatized firms' corporate survival over a period of 20 years.

Using this dataset, we document that on average, the Treuhand was more likely to privatize more productive firms. Firms with higher labor productivity were also privatized faster. The Treuhand's

\footnotetext{
${ }^{3}$ In West German opinion polls from the 1980s, typically less than ten percent of the respondents state that they expect to experience reunification within their lifetime (Herdegen, 1992).
} 
internal firm rating scores, which aimed to evaluate the firms' business situation and were used for prioritization, further substantiate these relationships. Next, we demonstrate that the more productive firms obtained higher sales prices but also higher employment and investment pledges. We then reveal that the more productive firms were also more likely to be sold to non-local owners, especially from West Germany. Finally, we show that firms' baseline labor productivity predicts their post-privatization survival in the short-, medium- and long-term. Conditional on higher baseline productivity, firms with West German or international owners were more likely to survive over periods of ten and 20 years. Overall, these findings can be interpreted as being in line with the Treuhand's legal mandate. However, it is beyond the scope of our analysis to assess whether the Treuhand's policy was optimal, or whether it would have been possible to achieve better allocations. Our study makes at least four key contributions to the existing literature. First, our analysis builds on the extensive literature regarding privatizations by highlighting that the probability of firms being selected for privatization as well as privatization speed depend on initial firm productivity. This finding contrasts classic theories of privatization which typically rationalize governments' privatization decisions based on efforts to maximize excess employment or other political benefits (Boycko, Shleifer, and Vishny, 1996; Laffont and Tirole, 1991; Shleifer and Vishny, 1994). Dinc and Gupta (2011) and Gan, Guo, and Xu (2018) find evidence of political motives in Indian and Chinese privatization decisions, respectively, but these motives may be less applicable to our institutional settings. Our findings also inform the empirical privatization literature where studies typically evaluate firms' post-privatization performance. Although selection bias in the privatization process has been acknowledged as the "most difficult problem" (Brown, Earle, and Telegdy, 2010, p. 693), the selection process itself has rarely been subject to examination (Megginson and Netter, 2001). Gupta, Ham, and Svejnar (2008) study the related problem of sequencing in privatization. Our finding that privatized firms are positively selected on productivity might raise identification concerns in post-privatization performance studies (see Estrin, Hanousek, Kočenda, and Svejnar (2009) for a review).

Second, our work relates to the literature on democratization and distribution, as we are the first to describe how public assets were privatized in East Germany and who became claimant to their profits. Theories of democratization place redistribution of wealth and firm ownership at their core (Acemoglu, Naidu, Restrepo, and Robinson, 2015). Dorsch and Maarek (2019) demonstrate that democratization has different consequences for income inequality depending on equality levels prior to democratization. Previously egalitarian yet autocratic societies may experience increases 
in inequality, while previously unequal autocracies may experience an income-leveling effect. Postcommunist countries such as Russia and China exhibit increasing wealth concentration at the top, which may be fueled by privatization (Novokmet, Piketty, Yang, and Zucman, 2018; Milanovic and Ersado, 2012). Guriev and Rachinsky (2005) track the ultimate shareholdings of Russia's business elites. Today's oligarchs often started out as Soviet government insiders or politically connected bankers who exploited privatizations to acquire major stakes and build up their fortunes. In contrast, we find that the most productive companies were not privatized to East German insiders but mostly to West German investors.

Third, our work relates to the sprawling literature on productivity differentials between firms of the same industries (Syverson, 2011). In line with Acemoglu, Akcigit, Alp, Bloom, and Kerr (2018), we find that productivity ensures firms' survival in competitive markets. The novelty of our findings derives from the German setting, where within-sector productivity differences are mainly inherited from a planning economy without factor markets. Studying Hungary, Orban (2019) finds that some initially labor-unproductive firms survived the transition by reducing over-staffing. In turn, we observe that unproductive East German firms were unlikely to survive the privatization process and remain in business for the subsequent 20 years.

Finally, we build upon existing empirical studies of East German privatization, which are surprisingly rare and focus on specific aspects. Analyzing the dynamics of the Treuhand's bargaining with buyers, Hau (1998) detects a subsidy bias towards large state-owned enterprises, which increases over time. His model rationalizes this finding as the option to liquidate gradually becomes politically infeasible in sectors affected by high unemployment. Dyck (1997) finds that the advent of market-experienced managers from West Germany is associated with performance increases of privatized firms. We complement these studies by providing the first comprehensive short- and long-term analysis of the Treuhand privatizations.

The remainder of this paper is structured as follows. In section 2, we review the historical background of the Treuhand privatizations. Section 3 introduces our data and section 4 outlines the empirical strategy. We present our results in section 5 and conclude in section 6 . 


\section{Privatization in East Germany}

In this section, we briefly review the main elements of the Treuhand privatizations, one of the largest privatization waves in history. The program resulted from the fall of the Berlin Wall, which culminated in the collapse of the GDR's central planning economy. The federal government of reunified Germany abolished the planning system and introduced the existing West German market institutions as well as regulations to the East. It also ended public ownership of the business sector. The Treuhand Law (TreuhG) and preceding legislation from the last socialist government required all state-owned enterprises to be transferred to the newly created Treuhand agency. On July $1^{\text {st }}$ 1990, the Treuhand owned more than 10,000 companies with about 4 million employees. These firms composed all listings of the GDR's registry of publicly owned operations (Kühl, Schaefer, and Wahse, 1991).

The Treuhand's objective was to "privatize quickly, restructure resolutely, and liquidate carefully" (Bundesanstalt für vereinigungsbedingte Sonderaufgaben, 2003). After assuming ownership of the state-owned enterprises, the Treuhand transformed them into companies under private law and divided large conglomerates into individual firms. Then, the Treuhand asked firms to compile opening balance sheets and submit business plans. The Leitungsausschuss, a committee of consultants comprising auditors, financial managers and banking experts subsequently evaluated the business situation. Funded by the Ministry of Finance, this committee issued recommendations for action that the Treuhand's board typically followed (Böick, 2018, p.285).

The main method of privatization was direct sales to potential investors. Large-scale auctions and voucher systems, which were implemented in several other countries, were not used ${ }^{4}$. In addition to developing an efficient economic structure, the Treuhand's task was also to maintain and create employment (TreuhG, Preamble). Hence, when negotiating with investors, the Treuhand also asked for employment and investment guarantees in addition to the sales price. Nevertheless, fierce protests by workers, unions, and politicians accompanied numerous privatization and liquidation decisions.

The Treuhand agency was a public-law corporation. However, the agency was overseen by a supervisory board and controlled by the Federal Ministry of Finance. The government instated the supervisory board and it drew its members from federal ministries, East German state governments, as well as business groups and unions. The supervisory board appointed the members of the executive board, and monitored their decisions. Moreover, the Federal Ministry of Finance had the

\footnotetext{
${ }^{4}$ See Bolton and Roland (1992) for a comparison of privatization policies in Germany, Czechoslovakia, Hungary, and
} Poland. 
right to review the Treuhand's decisions when the companies concerned exceeded certain size limits. At least partially reconstructing these limits, Figure 1 indicates that the ministry largely refrained from exercising its supervisory rights, especially for larger firms. ${ }^{5}$ Internally, the Treuhand created a two-tiered organizational structure, consisting of a headquarters in Berlin and fifteen regional branch offices. The headquarters was in charge of enterprises with more than 1,500 employees, with several exceptions. Regional branch offices were responsible for companies below this threshold, although the company database providing for a definite assignment only became available in April 1991. Despite the unique situation prevailing in East Germany, the Treuhand's institutional setting resembles structures deployed in other countries, such as the state property agencies in Hungary and Estonia (Carlin and Mayer, 1994; Purju, 1996).

Figure 1. Potential and Actual Monitoring by the Ministry of Finance

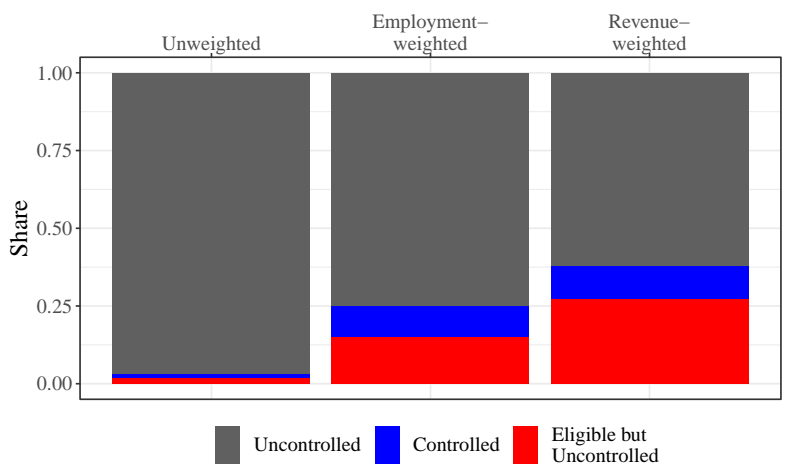

\begin{abstract}
Notes.- A Treuhand decision was eligible for review if the underlying firm size measured by employment, revenue, and balance sheet total surpassed specific thresholds. Using a list of contracts reviewed via parliamentary inquiry as well as employment and revenue figures from Söstra and we can identify which firms were monitored and unmonitored conditional on partial eligibility (Deutscher Bundestag, 1994). We can only identify a subset of eligible firms as we lack balance sheet information. Therefore, the group of firms that were not monitored might contain further eligible firms, and the group of controlled firms ineligible firms. Source.- Deutscher Bundestag (1994), BvS Firm Register, and THA Firm Surveys.
\end{abstract}

Several challenges exacerbated the Treuhand's efforts. East German firms generally suffered from overstaffing, outdated production technologies, the collapse of traditional export markets in the Soviet Union, and a lack of market experience. At the same time, currency reform and union bargaining substantially increased labor costs, further deteriorating the business situation (Dornbusch and Wolf, 1994). Akerlof, Rose, Yellen, and Hessenius (1991) illustrate the extent of these problems by analyzing the business situation of the GDR's major companies. These companies regularly exported products to clients outside the Soviet Union, allowing the authors to compare

\footnotetext{
${ }^{5}$ The size cutoffs give rise to a potential regression discontinuity design. Unfortunately, we do not observe firm balance sheet totals in so far we can only identify a subset of eligible firms. Moreover, thresholds were quite high to the extent that the number of firms potentially qualifying was low, even though their shares of total employment and revenue were systemically important.
} 
domestic resource costs for these products and their market-based export value in 1989 . The results paint a grim picture of the firms' competitiveness, given that the production costs of all but one of the 183 enterprises exceeded their respective revenues. Within this context, the Treuhand made significant concessions to potential buyers, including capital injections, debt redemptions, and the assumption of environmental liabilities. These types of subsidies commonly led to negative effective sales prices (Hau, 1998).

The Treuhand closed its operations on December $31^{\text {st }}, 1994$. Figure 2 shows that the Treuhand privatized almost 60 per cent of the firms it formally owned. Approximatively 30 per cent of firms were liquidated. The remainder is divided between firms restituted to former owners and firms municipalized. These comprise an even smaller share when we account for their size in terms of initial employment or revenues. The financial loss from the Treuhand's operations amounted to 256 billion DM, which was absorbed by the federal government (Bundesanstalt für vereinigungsbedingte Sonderaufgaben, 1994). The Bundesanstalt für vereinigungsbedingte Sonderaufgaben $(\mathrm{BvS})$ continued contract surveillance and other remaining tasks.

Figure 2. Final Firm Outcomes of Treuhand Operations
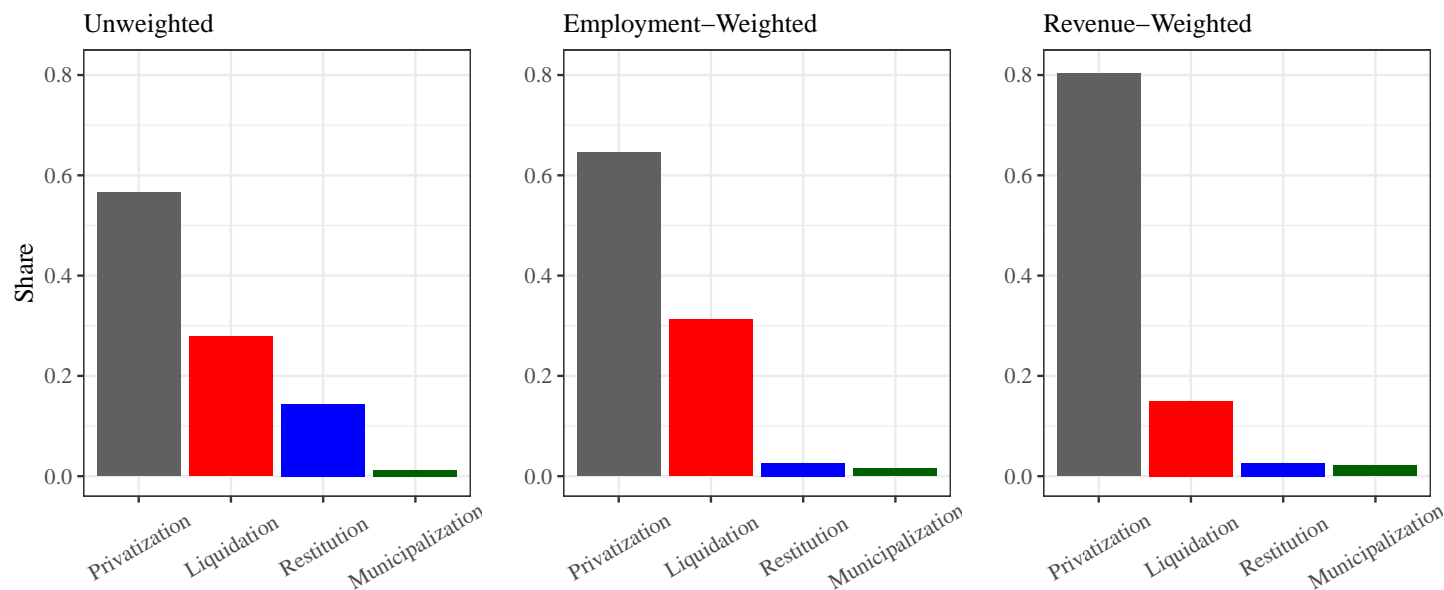

Note: Relative frequencies of final firm privatization outcomes. Initial employment and revenue used for weighting. Sources: BvS Firm Register and THA Firm Surveys.

\section{Data}

In this section, we describe the five key components of our analysis samples and explain our main variables. This is the first data set based on the whole universe of firms under the East German mass privatization program from 1990 until 2015. It comprises an administrative firm register supplemented with data on initial labor productivity, firm rating scores, sales prices as well as other 
contractual features, and post-privatization firm ownership as well as corporate survival over a period of 20 years.

BvS Firm Register. An administrative register of 12,874 firms owned by the Treuhand forms the core of our sample, which we supplement with further data sources as needed. The register includes the full population of Treuhand firms and derives from original Treuhand records. We obtained the register from the Treuhand's successor agency BvS (Bundesanstalt für vereinigungsbedingte Sonderaufgaben, 2016). In addition to basic firm information, it includes the firms' status following Treuhand ownership. Their status indicates if a firm was privatized, liquidated, restituted to its formerly expropriated owners, or municipalized (see Figure 2 in the previous section). Our final sample focuses on privatized and liquidated firms, as decisions to restitute or municipalize were largely taken outside the Treuhand's purview and followed predetermined criteria. We also exclude firms headquartered outside the former GDR, as well as operations solely providing active labor market programs.

Treuhand Firm Surveys. We compile baseline labor productivity indicators from surveys of current and former Treuhand companies (Kühl, Schaefer, and Wahse, 1991). As of April 1991, the SÖSTRA Institute, Berlin, on behalf of the Treuhand and Federal Employment Agency, conducted these surveys biannually. Using the employment and revenue items included in the survey, we develop two major labor productivity indicators: revenues per worker and revenues per hour. The former is a standard indicator as also used by Decker, Haltiwanger, Jarmin, and Miranda (2017). The latter indicator additionally captures differences in firms' use of short-time work schemes; 22 per cent of East German employees were in short-time schemes as of February 1991 (Akerlof, Rose, Yellen, and Hessenius, 1991). As we aim to construct a cross-section of firms' initial labor productivity, we invariably use the earliest response available for each firm. In about 90 per cent of all cases, the labor productivity variable refers to 1992 or earlier. Surveys conducted after September 1993 also include the value of external inputs as a share of total revenues, thus allowing us to draw up a measure of firms' gross value added. Due to the late survey dates and a lower number of observations, we use this indicator only for sensitivity analyses. All financial variables are deflated to the base year 2000 using prize indices from OECD (2015). We follow the suggestion of Bollinger and Chandra (2005) and apply a one per cent winsorizing rule to these variables due to potential measurement error. Labor productivity indicators are available for 6,015 Treuhand firms. For privatized firms, the data includes the month of privatization. 
Treuhand Firm Ratings. We extract internally used rating scores that were awarded to firms administered by the Treuhand's headquarters. We extract these scores from meeting protocols of the Treuhand's Leitungsausschuss, which we collected from the German Federal Archive (Bundesarchiv, 2019). We extract all available rating scores awarded until June 1991, covering the first year of the Treuhand's four and a half years of existence. This data comprises 584 scores for firms that can be matched with the BvS firm register. Restricting ourselves to the ratings awarded in the initial year ensures that scores plausibly represent the internal assessment of a firm, rather than the demand from investors that the Treuhand would observe over time. Scores comprise values between one and six. A score of one implies that a firm is profitable, and has no need for further restructuring. Conversely, a score of six means that the firm was not considered viable even with further restructuring and recommended direct liquidation.

Treuhand Contract Data. We employ administrative Treuhand data on privatization contracts from Hau (1998). For firms privatized prior to December 1993, this data comprises the sales price as well as the amount of employment and investment commitments made by the buyer in negotiation with the Treuhand. These contracts are available for 2,148 of our firms.

MUP Firm Register. We enrich the data on Treuhand-administered firms by adding information on post-privatization ownership and corporate survival from the Mannheim Enterprise Panel (MUP). The MUP is based on commercial register data provided by Creditreform, Germany's

Figure 3. Dataset Construction

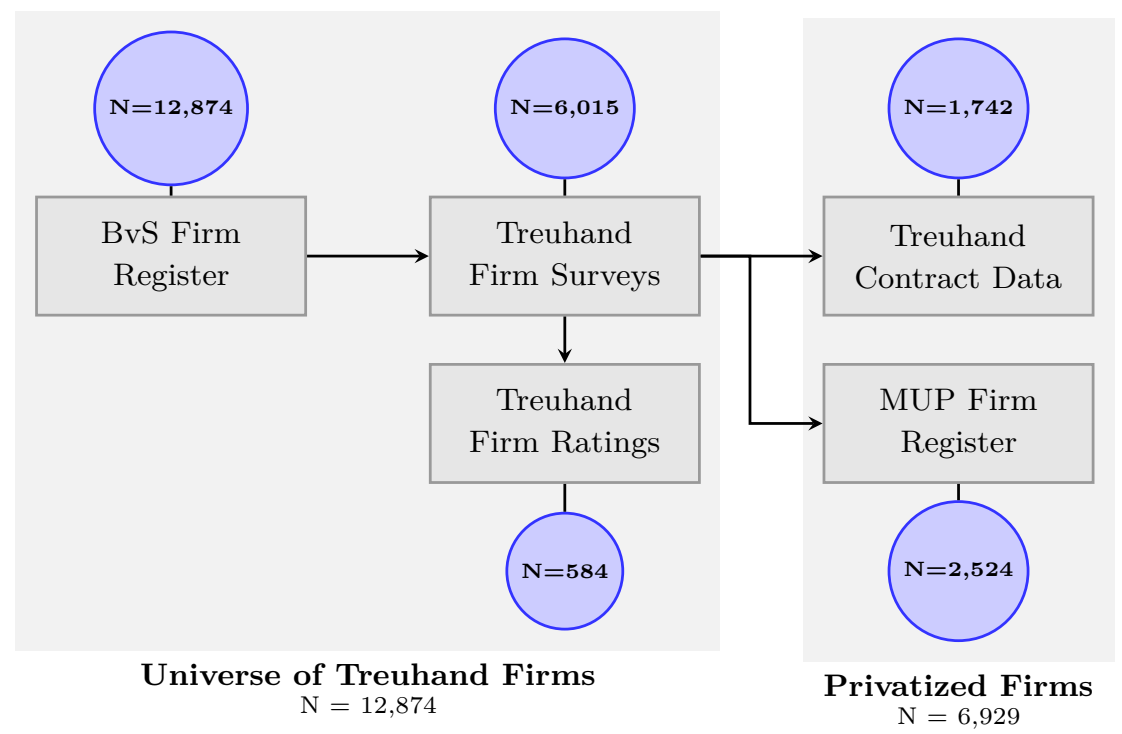


largest corporate credit rating agency (Bersch, Gottschalk, Mueller, and Niefert, 2014). This data encompasses the entirety of firms active in East Germany from 1993 onwards. Hence, most firms currently or formerly owned by the Treuhand are included in the database. Our data collection includes information on ownership, ownership location, closure date, and legal form. We also extract the number of employees for years following the Treuhand regime. Ownership information encompasses the address of the owners, information on whether they are a firm or a natural person, as well as indicators for the type of ownership (shareholding, owner-manager etc.); it is limited to direct or first-level ownership, however. We jointly observe ownership, survival data, and labor productivity indicators for 2,524 firms privatized by the Treuhand.

Figure 3 demonstrates the data construction process. Table A.1 describes our main variables and outlines their summary statistics. Table 1 illustrates the balancing of firm characteristics across our samples. 
Table 1. Sample Comparison

\begin{tabular}{|c|c|c|c|c|c|}
\hline \multirow[b]{2}{*}{ Data Sources } & \multicolumn{5}{|c|}{ Sample } \\
\hline & Section 2 & Section 5.1 .1 & Section 5.1 .2 & Section 5.2 & Section 5.3-5.4 \\
\hline $\begin{array}{l}\text { BvS Firm Register } \\
\text { Treuhand Firm Surveys } \\
\text { Treuhand Firm Ratings } \\
\text { Treuhand Contract Data } \\
\text { MUP Firm Register }\end{array}$ & $\checkmark$ & $\begin{array}{l}\checkmark \\
\checkmark\end{array}$ & $\begin{array}{l}\checkmark \\
\checkmark \\
\checkmark\end{array}$ & $\begin{array}{l}\checkmark \\
\checkmark \\
\checkmark\end{array}$ & $\begin{array}{l}\checkmark \\
\checkmark\end{array}$ \\
\hline Firm Characteristics & & & & & \\
\hline $\begin{array}{l}\text { State } \\
\text { Brandenburg }\end{array}$ & $\begin{array}{c}0.138 \\
(0.345)\end{array}$ & $\begin{array}{c}0.145 \\
(0.352)\end{array}$ & $\begin{array}{c}0.144 \\
(0.351)\end{array}$ & $\begin{array}{c}0.145 \\
(0.352)\end{array}$ & $\begin{array}{c}0.132 \\
(0.338)\end{array}$ \\
\hline Mecklenburg West. Pom. & $\begin{array}{c}0.107 \\
(0.310)\end{array}$ & $\begin{array}{c}0.106 \\
(0.307)\end{array}$ & $\begin{array}{c}0.057 \\
(0.231)\end{array}$ & $\begin{array}{c}0.088 \\
(0.284)\end{array}$ & $\begin{array}{c}0.099 \\
(0.299)\end{array}$ \\
\hline East Berlin & $\begin{array}{c}0.085 \\
(0.280)\end{array}$ & $\begin{array}{c}0.089 \\
(0.286)\end{array}$ & $\begin{array}{c}0.089 \\
(0.285)\end{array}$ & $\begin{array}{c}0.061 \\
(0.240)\end{array}$ & $\begin{array}{c}0.087 \\
(0.282)\end{array}$ \\
\hline Saxony & $\begin{array}{c}0.332 \\
(0.471)\end{array}$ & $\begin{array}{c}0.330 \\
(0.470)\end{array}$ & $\begin{array}{c}0.337 \\
(0.473)\end{array}$ & $\begin{array}{c}0.336 \\
(0.472)\end{array}$ & $\begin{array}{c}0.319 \\
(0.466)\end{array}$ \\
\hline Saxony-Anhalt & $\begin{array}{c}0.176 \\
(0.381)\end{array}$ & $\begin{array}{c}0.169 \\
(0.375)\end{array}$ & $\begin{array}{c}0.200 \\
(0.401)\end{array}$ & $\begin{array}{c}0.178 \\
(0.382)\end{array}$ & $\begin{array}{c}0.185 \\
(0.388)\end{array}$ \\
\hline Thuringia & $\begin{array}{c}0.161 \\
(0.367)\end{array}$ & $\begin{array}{c}0.160 \\
(0.367)\end{array}$ & $\begin{array}{c}0.173 \\
(0.378)\end{array}$ & $\begin{array}{c}0.192 \\
(0.394)\end{array}$ & $\begin{array}{c}0.178 \\
(0.382)\end{array}$ \\
\hline Employment & $\mathrm{n} / \mathrm{a}$ & $\begin{array}{c}362.6 \\
(680.3)\end{array}$ & $\begin{array}{c}909.6 \\
(1115.0)\end{array}$ & $\begin{array}{c}394.7 \\
(702.5)\end{array}$ & $\begin{array}{c}346.2 \\
(638.5)\end{array}$ \\
\hline Log Revenue per Worker & $\mathrm{n} / \mathrm{a}$ & $\begin{array}{c}4.290 \\
(1.047)\end{array}$ & $\begin{array}{c}3.893 \\
(1.067)\end{array}$ & $\begin{array}{c}4.240 \\
(0.939)\end{array}$ & $\begin{array}{c}4.436 \\
(0.981)\end{array}$ \\
\hline Log Revenue per Hour & $\mathrm{n} / \mathrm{a}$ & $\begin{array}{c}3.752 \\
(0.968)\end{array}$ & $\begin{array}{c}3.425 \\
(0.952)\end{array}$ & $\begin{array}{c}3.720 \\
(0.788)\end{array}$ & $\begin{array}{c}3.875 \\
(0.873)\end{array}$ \\
\hline Manufacturing Share & $\mathrm{n} / \mathrm{a}$ & $\begin{array}{c}0.659 \\
(0.474)\end{array}$ & $\begin{array}{c}0.851 \\
(0.354)\end{array}$ & $\begin{array}{c}0.993 \\
(0.356)\end{array}$ & $\begin{array}{c}0.712 \\
(0.453)\end{array}$ \\
\hline Observations & 12,874 & 6,015 & 584 & 1,778 & 2,524 \\
\hline
\end{tabular}

Note.- Table provides means and standard deviations (in parentheses) for major variables. Each column represents a sample used in this study that comprises one or several data sources. BvS data is a firm register and does not include industry, firm size, or firm performance. BvS and Söstra data represent all Treuhand firms. Leitungsausschuss only comprises firms steered by the Treuhand headquarter (i.e. larger firms). Hau contract sample is bound to privatized manufacturing firms. MUP includes privatized firms from all industries.

Sources.- BvS Firm Register, THA Firm Surveys, THA Firm Ratings, THA Contract Data, MUP Firm Register.

\section{Empirical Strategy}

Our analysis combines parametric and non-parametric approaches. We begin analyzing each stage of the privatization process by providing graphs depicting the relationship between quantiles of the productivity distribution across firms and the outcome of interest. This enables us to perform an initial assessment of the relationship without relying on strong parametric assumptions. In the next stage, we apply ordinary least squares regressions to account for potential confounding factors and yield the best linear approximation of the respective conditional expectation function. We have 
chosen this framework in order to document general statistical relationships, rather than specific point estimates. In particular, we estimate models of the form

$$
Y_{i}=\gamma \text { Productivity }_{i}+\delta_{s}+\mu_{l}+\nu_{t}+\varepsilon_{i}
$$

where $Y_{i}$ denotes an outcome variable of firm $i$ that is the probability to be privatized, the time to privatization, privatization contract characteristics, or post-privatization survival, depending on the question studied. We regress the firm outcome on a firm productivity indicator with $\gamma$ being our coefficient of interest. The regression includes industry fixed effects $\delta_{s}$ at the three-digit level to account for general industry differences and for public support programs that may have benefited particular industries. As the six East German states (including East Berlin) may have employed various local strategies for economic development, state fixed effects $\mu_{l}$ account for policy differences and other geographic heterogeneity. Finally, survey fixed effects $\nu_{t}$ are dummies for the survey wave from which the productivity variables have been collected. They control for the measurement timing of these variables since they rely on macroeconomic and seasonal conditions, while also capturing survey-specific factors. The underlying assumption is that the covariates are the only source of correlation between Productivity P $_{i}$ and $\varepsilon_{i}$. We use Eicker-Huber-White standard errors throughout to deal with potential heteroscedasticity. We test the robustness of our correlations with alternative fixed-effects such as firm employment size categories, decentralization of decisions to local agency branches, administrative districts and four digit industries in our appendix.

\section{The Role of Labor Productivity for Privatization Decisions and Long-run Firm}

\section{Outcomes}

\subsection{Privatization Decisions.}

5.1.1. The Role of Labor Productivity in Privatization Decisions. We begin by examining whether companies that are more productive had an increased chance of becoming privatized. A widespread critique of privatization in East Germany has been that economically sound firms were closed, despite the Treuhand's statutory responsibility having been to develop businesses that could be restructured and privatized. In order to test the agency's fulfillment of this responsibility, we expect firms that are more productive to be associated with higher privatization rates. For successful privatization, the productivity level of a firm would need to be high enough to survive in a competitive market environment. Otherwise, the privatization agency would spend scarce financial and personnel 
resources on unsustainable privatization cases. Several political and economic forces may threaten this goal. First, the privatization agency may experience pressure from politicians who prioritized protecting their constitutents' jobs notwithstanding the productivity of the firms (Grossman and Helpman, 1996; Faccio, Masulis, and McConnell, 2006; Hodler and Raschky, 2014). For instance, anecdotal evidence suggests that Chancellor Helmut Kohl's visit to the so-called chemical triangle around Halle (Saxony-Anhalt) in 1992 saved the major companies from liquidation. The Treuhand therefore granted generous financial support to buyers, despite an expert's report by the consulting firms Arthur D. Little and McKinsey having attested that these companies were not economically viable (Lamparter, 1992). Second, the privatization agency may have experienced institutional capture as almost the entire executive level of the Treuhand was recruited from West German companies. These companies may have feared the emergence of strong competitors from the East, and thus try to prevent the privatization of especially productive firms.

Analogous to the link between labor productivity and privatization decisions, more productive firms would also benefit from faster privatization and receiving a higher priority from the privatization agency. If productive firms were privatized sooner, the agency could focus on the more cumbersome cases remaining in its portfolio. This practice would also be consistent with the Treuhand's mandate to privatize as soon as possible. In the following section, we study firms' baseline labor productivity and its relationship with the privatization outcome itself, as well as the speed of privatization.

We first graphically summarize our findings. The graph on the left in Figure 4 presents the association between firms' percentile ranks in the overall labor productivity distribution and the share of privatized firms per rank. Focusing on percentile ranks offers an effective yet simple non-parametric safeguard against potential outliers and nonlinearities. The figure shows the overall tendency among firms with higher revenue per worker or revenue per hour to experience higher rates of privatization. Firms at the bottom of the labor productivity distribution were privatized at a rate of below 40 per cent, whereas firms at the top of the distribution experienced privatization rates of about 70 per cent. Given that a firm was privatized, the graph on the right presents an analogous tendency for labor productivity and the time until privatization. The least productive firms found an investor after some 29 months, whereas the most productive firms could expect privatization to take place as early as within 24 months. These patterns strongly support the role of productivity in privatization decisions, but a major concern is that these tendencies simply reflect industry-effects.

Table 2 provides the results of the corresponding ordinary least squares regressions that also control for industry fixed-effects, state fixed-effects, and survey-time fixed effects. Columns (1) and (2) 
Figure 4. Privatization, Time to Privatization, and Baseline Productivity
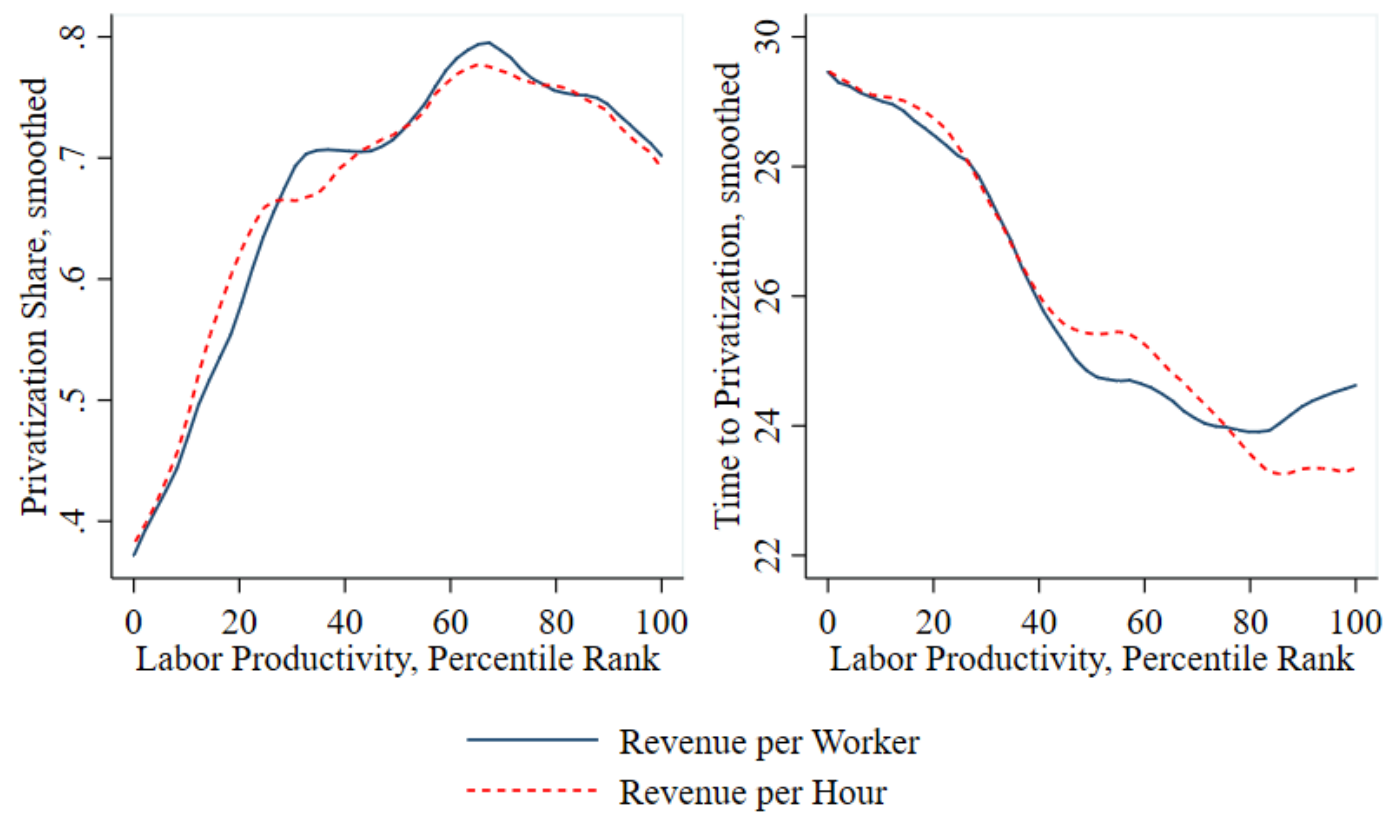

Note: Rank coefficients calculated using Hazen's rule. Smoothing procedure uses an Epanechnikov kernel function of degree zero.

Sources: BvS Firm Register and THA Firm Surveys.

confirm that a firm's privatization probability increases with its baseline labor productivity as given by revenue per worker or revenue per hour. In particular, a ten per cent increase in revenues per worker raises the expected privatization probability by 0.79 p.p. Columns (3) and (4) repeat the same models for the time before privatization takes place. The resulting coefficients suggest that a ten per cent increase in revenues per worker roughly corresponds to a 13-months reduction in this period; a 17-months reduction is suggested when using revenues per hour as our measure of labor productivity.

We subsequently assess the robustness of these associations by altering our basic regression model. Table A.2 in the appendix summarizes these results for the privatization probability; Table A.3 does this for the time until privatization. As larger firms may be more productive and less likely to be liquidated, we first assess whether our specification is robust by including firm size dummies according to the classification by Haltiwanger, Hyatt, Kahn, and McEntarfer (2018). These authors differentiate firms with less than 50 employees, firms between 50 and 500 employees, and firms with more than 500 employees. The corresponding results presented in column (1) strongly reaffirm 
Table 2. Regression Results: Privatization, Time to Privatization and Productivity

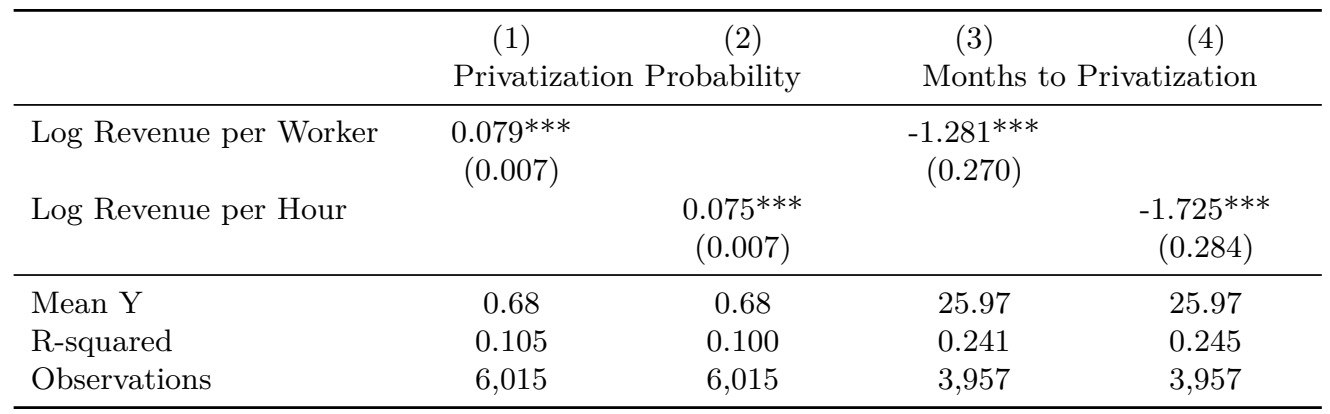

Notes.- Each column presents an OLS regression with industry FE (3-digit), state FE, and survey-time FE. The outcome variable for columns (1) and (2) is a dummy equaling 1 if a firm was privatized at the end of 1994 and 0 otherwise. For column (3) and (4) the outcome is the number of months until privatization. Robust standard errors given in parentheses. ${ }^{*} p<0.1 ;{ }^{*} p<0.05 ;{ }^{* * *} p<0.01$. Sources.- BvS Firm Register and THA Firm Surveys.

our previous estimates. We then ask whether our results are equally valid for the subsample of manufacturing firms, as major studies of privatization are restricted to the industrial sector (see, e.g. Frydman, Gray, Hessel, and Rapaczynski, 1999; Brown, Earle, and Telegdy, 2006, 2010). Column (2) suggests that the association between labor productivity and privatization is even stronger for manufacturing firms. Potential explanations might be that the concept of labor productivity is more salient for manufacturing firms and that privatized manufacturing firms are an even more selective group. In column (3), we inquire whether we reach similar conclusions with more specific measures of productivity, such as the firm's gross value added. The resulting coefficient shows that using this indicator leads to the same qualitative result. As this indicator derives from surveys further away from the base period and is only available for a smaller sample, we do not include it in our initial estimates. In the next step, we ask whether it is possible to explain the productivity-privatization link by performance differences with regard to how a firm was directed among the Treuhand headquarters and the fifteen regional branch offices. As column (4) demonstrates, adding a full set fixed effects for branch offices and headquarters to our model does not alter the relationship between productivity and privatization probability or time. The model presented in column (5) analyzes the potential role of geographical heterogeneity, as firms close to West Germany could, be more productive and more marketable at the same time, for instance. However, adding district fixed effects to our model corroborates the initial findings. Similarly, using a more finely tuned industry classification (four-digit level) leaves these relationships unchanged, as summarized in column (6).

Finally, we address the concern that break-ups of former publicly-owned companies (Volkseigene Betriebe, short VEB) systematically split firms along productivity differences. Productivity differences across Treuhand firms then would not originate from the GDR but the Treuhand's 
restructuring activities. We assess this argument by aggregating our Treuhand firm data at the level of former VEBs. In addition, we drop firms indicated as spin-offs that cannot directly be linked to a former VEB. Table A.4 presents the results based on this smaller sample. We still find the same tendencies in privatization patterns and privatization speed as observed in Table 2. The coefficient magnitude is slightly smaller for the decision to privatize and slighly larger for the time to privatization. Overall, we show that these initial estimates are robust to a wide range of plausible objections and conclude that there is a meaningful statistical association between firms' initial labor productivity, and their chances of a successful privatization process.

5.1.2. Explaining Privatization Patterns: The Role of Treuhand Policies. We now explore the underlying reasons for the positive selection of firms into privatization. As the Treuhand held a screening function within the privatization process, an obvious choice would be to attribute this tendency to the stringent work of the privatization agency. For example, Roland (1994) argues that a privatization program must separate economically sound firms from unsound ones, since large-scale privatizing of the latter would undermine the financial system's stability. However, it is equally feasible that investors' higher demand for more productive firms leads to such a sorting pattern. To examine whether the Treuhand played a role in distinguishing between productive and non-productive firms, we analyze internal firm rating scores assigned to firms managed by the Treuhand headquarters ${ }^{6}$. These rating scores commonly determined whether a firm would retain continued financial support and privatization assistance. If these ratings were part of a successful screening mechanism, better scores would correlate with higher baseline labor productivity and predict privatizations rather than liquidations.

Figure 5 presents the results. The y-axis on the left depicts firms' percentile ranks in the revenue per worker distribution in the subset of rated firms. The upward slope of the solid line suggests that firms with smaller (i.e. better) internal rating scores are also more productive at baseline. On average, firms with the worst rating score (6) exhibit productivity levels around the 40th percentile rank. In contrast, firms rated with the best score (1) rank about 25 percentiles higher in the distribution. Thus, the rating scores used by the Treuhand capture productivity differences. Subsequently, we want to find out whether better scores also predict privatization chances as measured by the y-axis on the right. The dashed line shows that better rating scores go hand in hand with higher privatization shares. The best rating score is associated with privatization shares amounting to approximately 80 per cent, whereas firms rated with the worst score manage

${ }^{6}$ Firms managed by the Treuhand branch offices, typically much smaller in size, did not receive standardized firm rating scores. 
Figure 5. Labor Productivity, Internal Firm Rating Scores, and Privatization

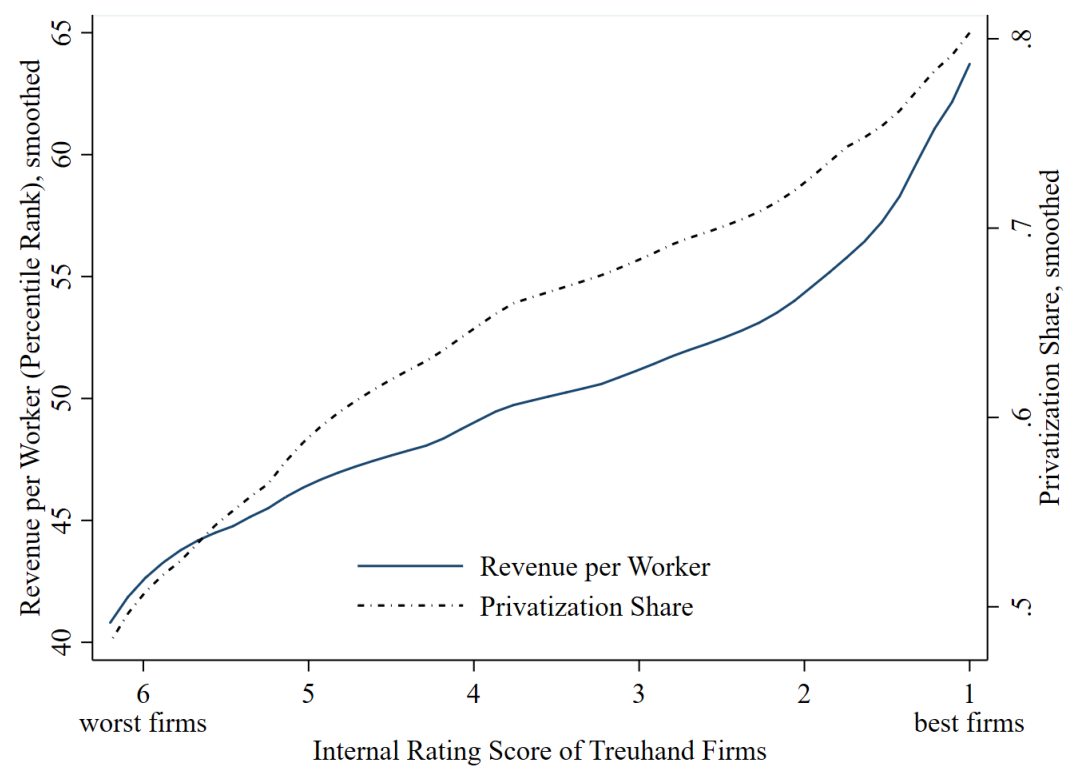

Note: Rank coefficients calculated using Hazen's rule. Smoothing procedure uses an Epanechnikov kernel function of degree zero.

Sources: BvS Firm Register, THA Firm Surveys, and THA Firm Ratings.

privatizations in less than half of the cases. This finding supports the interpretation that the Treuhand's screening policies were effective in identifying productive firms independent of investor demand, which later corresponds to more privatizations and fewer liquidations of productive firms.

\subsection{Privatization contracts: Contrat social or contrat maximal?}

In this section we examine the relationship between firm productivity and privatization contracts. The Treuhand pursued multiple goals in its negotiations with potential buyers. Bids did not only contain a sales price, the Treuhand also demanded employment and investment guarantees, restructuring of management, and the general continuation of business activity (Treuhandanstalt, 1994). The heavy financial and employment losses, which became apparent with the end of the agency's operations, drew criticism to its sales strategy. In a recent parliamentary debate Dietmar Bartsch from the party The Left stated his conclusion "The Treuhand has turned the East into a junk shop" (Adler, 2019).

Using data on final privatization contracts realized between buyers and the Treuhand by Hau (1998), we examine whether contracts are signed with higher sales prices, employment as well as investment 
guarantees for companies that are more productive. We expect the contractual outcomes to increase with labor productivity, provided the Treuhand's bargaining power and idiosyncratic valuation of firms by bidders are both increasing functions of productive efficiency of labor. Figure 6 exhibits upward curves for sales prices, job guarantees, and investment promises along our measures of labor productivity. Both measures of labor productivity show similar patterns. Prices and investment pledges increase linearly, employment pledges seem to hit a ceiling at the 60th and 80th productivity percentile, respectively.

Figure 6. Sales Prices, Employment and Investment Guarantees, and Productivity
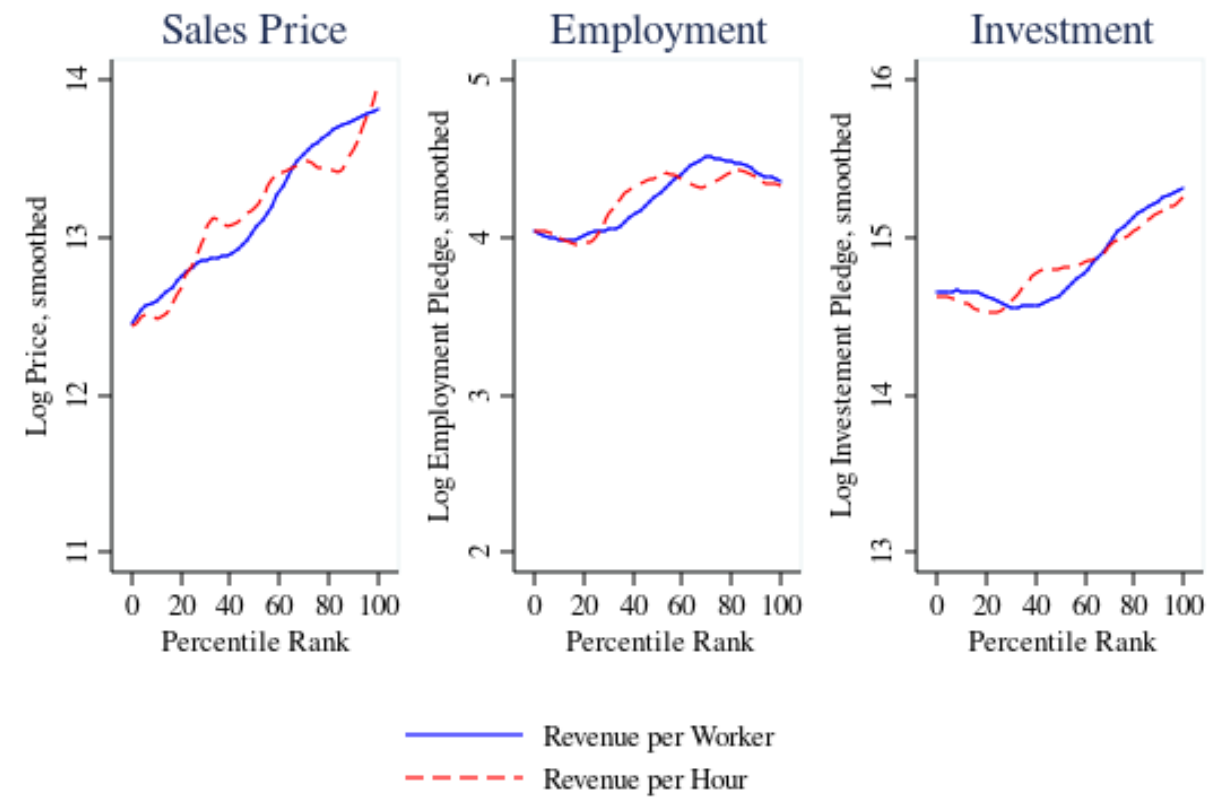

Note: Rank coefficients calculated using Hazen's rule. Smoothing procedure uses an Epanechnikov kernel function of degree zero.

Sources: THA Firm Surveys, THA Contract Data and own calculations.

We regress each contract criterion separately on labor productivity. A challenge confronting us is that we cannot distinguish between zeros and missing values due to the technical heritage of the contract data. We therefore use truncated regressions models, truncating contract outcomes at zero. Table 3 reports average marginal effects from truncated outcomes models. Column (1) can be interpreted such that a one log-point increase in initial productivity increases sales prices on average by $0.35 \mathrm{log}$-points, and $0.40 \mathrm{log}$-points respectively. Hence, the Treuhand was more likely to sell productive firms at higher prices as opposed to less productive firms. This correlation is robust when controlling for variation across survey-times, states, and industries. The legally binding guarantees for job preservation in column (2) are associated with increases of around 0.11 and 0.14 
log-points respectively. Investment guarantees in column (3) increase by 0.16 to 0.20 log-points on average when firm productivity increases by one log-point. We perform the same robustness checks in the Appendix in Table A.5, A.6, and A.7 as in the previous section and demonstrate that our results hold throughout all three outcomes obtaining similar magnitudes and significance levels. Anecdotal evidence exists about undervalued insider sales in the instance of the local branch of the Treuhand in Halle (Renken and Jenke, 2001). Results in A.5 show that the correlation between productive efficiency and sales prices hold within local branches across the entire sample.

It would be worth evaluating these magnitudes against the background that the agency did not raise enough revenue to cover its costs. Yet, as we do not observe the budget constraints faced by the agency and potential buyers, we cannot view our findings as evidence that the agency exhausted its bargaining power. In order to subject firm values and the sales process to a more systemic evaluation, detailed balance sheets of the Treuhand companies and the content of competing bids are required. It is tempting to interpret differences between coefficients as preference on the part of the agency for maximizing revenue as opposed to guaranteeing employment. However, we do not observe the corporate cost structure of buyers to finance acquisitions, such that job guarantees could have simply been more expensive for corporate buyers than sales prices in the long-term.

Table 3. Contractual Outcomes and Productivity

\begin{tabular}{lcccccc}
\hline & \multicolumn{2}{c}{ Log Price } & \multicolumn{2}{c}{ Log Employment Pledge } & \multicolumn{2}{c}{ Log Investment Pledge } \\
& $(1)$ & $(2)$ & $(3)$ & $(4)$ & $(5)$ & $(6)$ \\
\hline Log Rev. per Worker & $0.353^{* * *}$ & & $0.114^{* *}$ & & $0.156^{* * *}$ \\
& $(0.092)$ & & $(0.046)$ & & $(0.058)$ & \\
Log Rev. per Hour & & $0.408^{* * *}$ & & $0.143^{* * *}$ & & $0.202^{* * *}$ \\
& & $(0.093)$ & & $(0.046)$ & & $(0.062)$ \\
\hline Mean Y & 13.17 & 13.17 & 4.24 & 4.24 & 14.81 & 14.81 \\
Observations & 1,494 & 1,494 & 1,627 & 1,627 & 1,548 & 1,548 \\
\hline
\end{tabular}

Notes. ${ }^{*} p<0.1 ;{ }^{* *} p<0.05 ;{ }^{* *} p<0.01$. Each column presents average marginal effects from left-truncated regression models with survey-time FE, industry FE (3-digit), and state FE. The outcome variables are sales price (column 1) and contractual investment pledge (column 3) in nominal Deutsche Mark (DM) and the guaranteed number of employees (2). As missing values are indistinguishable from zeros the outcomes are truncated at 0 . Positive values are log-transformed. Robust standard errors given in parentheses. 
5.3. Post-Privatization Firm Ownership. In this section, we examine the post-privatization ownership distribution of formerly state-owned firms in relation to their productivity. Existing studies of privatization have repeatedly highlighted the importance of ownership types for firm performance. However, Djankov and Murrell (2002) and Estrin, Hanousek, Kočenda, and Svejnar (2009) note that firms may not only be selected for privatization but also for different types of private ownership. Our analysis corroborates and illustrates the pertinence of these selection dynamics.

The Treuhand's legal mandate specified that ownership changes were to be achieved as quickly and extensively as possible (TreuhG, Preamble). In the context of East Germany, emphasizing speed and extent of ownership change could mean favoring West German and international investors over potential new owners from the former GDR. This is because these investors probably had the upper hand in terms of market experience, managerial expertise, and access to financial or political capital. However, the privatization agency also had to account for the wider implications of redistributing firm ownership. Even in developed economies, shareholding is often highly concentrated (La Porta, Lopez-De-Silanes, and Shleifer, 1999). Concentrated and non-local capital ownership can have a negative impact on wealth equality (Piketty, 2014, 2015) and on economic growth (Alesina and Rodrik, 1994). As such, ownership decisions represent a meaningful trade-off in the Treuhand privatization program.

Indeed, a prominent critique in public discourse surrounding privatizations in East Germany is that the Treuhand favored West German investors and allowed them to assume ownership of the productive industrial assets of the East. In this section, we document the extent to which the Treuhand sold East German firms to West German investors, and whether West German investors secured ownership of the economy's most productive firms. To this end, we use firm-level ownership data obtained from the MUP Firm Register, and match them with additional information on firms' productivity that we gather from the THA Firm Surveys.

First, we look at the distribution of ownership for firms privatized by the Treuhand. Figure 7 plots majority ownership at the end of official Treuhand activities in 1995. The figure displays a measure of majority ownership based on the absolute number of shareholdings. Majority ownership is attributed to West German or international owners if they represent (or are tied for) the largest group of owners. Majority shareholdings based in the reunified Federal State of Berlin are attributed to West Germany. For Treuhand firms owned by firms located in East Germany in the post-privatization stage, we also assess whether the firms themselves are potentially owned from outside East Germany. That way, we account for potentially complex forms of ownership where non-local investors set up 
Figure 7. Majority Ownership distribution of privatized firms in 1995

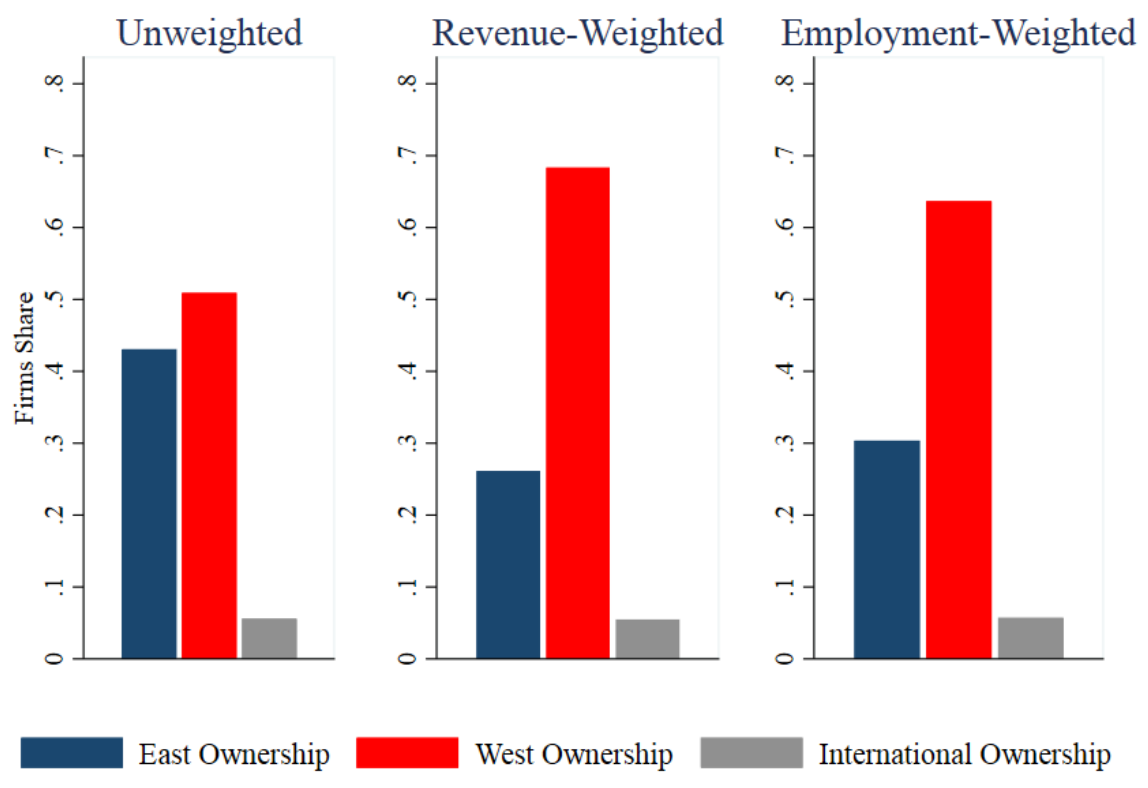

Note: Shares of privatized firms with a majority of owners from East Germany/West Germany/Outside of Germany in 1995. Unweighted, weighted by initial revenue, and weighted by intial employment. $\mathrm{N}=2,524$.

Sources: BvS Firm Register and MUP Firm Register.

holding companies within the territory of the former GDR. The mean values depicted in Figure 7 document a prevalence of West German ownership in Treuhand firms. 51.0 per cent of privatized Treuhand firms are majority-owned by West German investors. When firms are weighted by their initial employment and revenue, the share of West German majority ownership rises to 63.7 per cent and 68.3 per cent, respectively. These results support the notion that most of the East German industrial capital did indeed end up in West German ownership. In particular, the results using employment and revenue weights imply that this trend is more pronounced for larger firms.

Given the overall distribution of post-Treuhand firm ownership, we now investigate which types of firms were most likely to have ended up in East German and West German ownership. In particular, we study how majority firm ownership varies depending on firm-level productivity. As before, we focus on pre-privatization indicators of labor productivity as indicators of firm efficiency and quality. Figure 8 displays percentile rank plots for East and West German majority ownership across the productivity distribution of privatized firms. The plots illustrate that most variation in majority ownership occurs in the upper half of the productivity distribution. Neither East nor 
Figure 8. Majority by Initial Productivity (Privatized Firms)
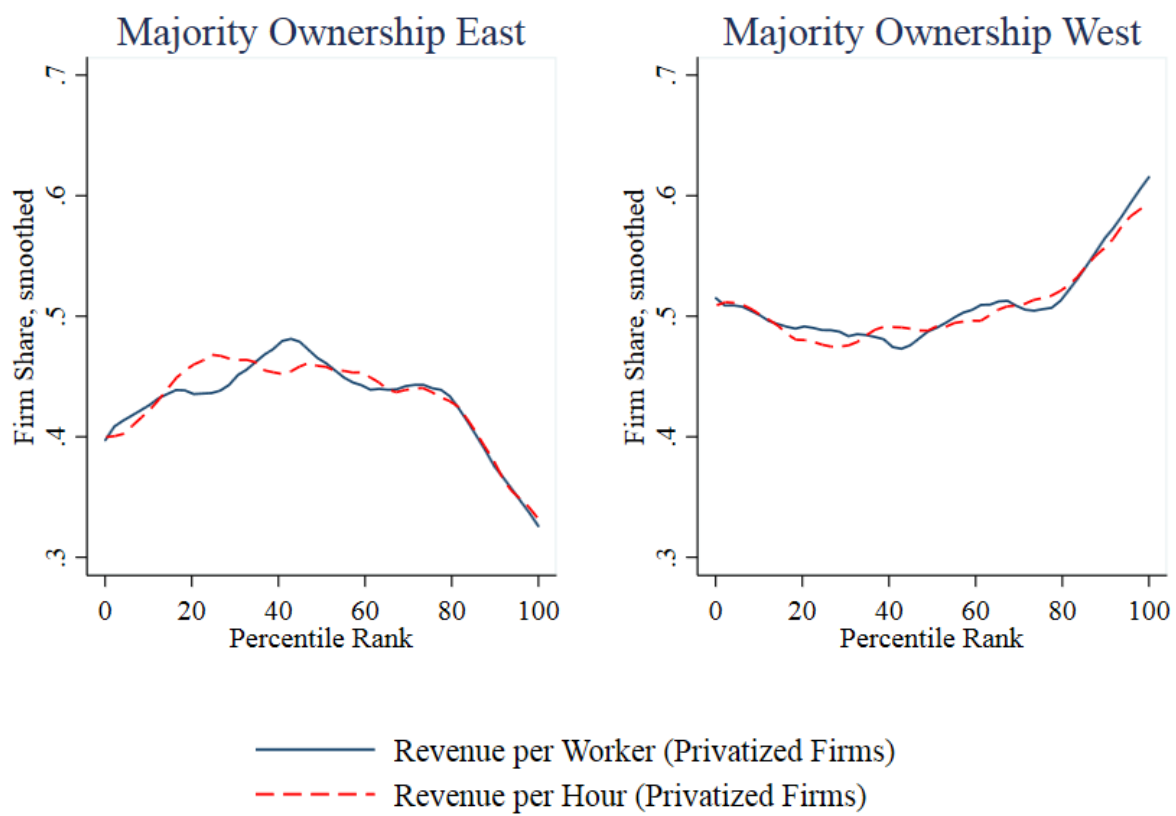

\footnotetext{
Note: Share of privatized firms with a majority of owners based in West (East) Germany in 1995 . Rank coefficients calculated using Hazen's rule. Smoothing procedure uses an Epanechnikov kernel function of degree zero. Firms with international majority ownership are not depicted (5.6\% of privatized firms). N $=2,524$.

Sources: BvS Firm Register, Treuhand Firm Surveys, and MUP Firm Register.
}

West German majority ownership strongly correlates with productivity below the 60th productivity percentile. However, Figure 8 shows noticeable divergence above the 60 th percentile. West German ownership is positively correlated with productivity, while East German ownership suggests a negative correlation for these most productive firms.

We complement this graphical summary of our results with a regression analysis in Table 4. Here, we regress binary indicators of majority ownership from East Germany, West Germany, and outside Germany on measures of initial firm productivity and several controls. The results emphasize the heterogeneity in ownership outcomes across the productivity distribution. We find statistically meaningful correlations for both East and West German ownership. East German majority ownership significantly decreases in firm productivity, while West German majority ownership displays a significant and positive relationship with productivity measures. Generally, a unit increase in log productivity is associated with an increase of 2.8 percentage points in West German majority ownership. 
Table 4. Majority Ownership by Initial Productivity for Privatized Firms

\begin{tabular}{lcccccc}
\hline & \multicolumn{2}{c}{ East Ownership } & \multicolumn{2}{c}{ West Ownership } & \multicolumn{2}{c}{ Int'l Ownership } \\
& $(1)$ & $(2)$ & $(3)$ & $(4)$ & $(5)$ & $(6)$ \\
\hline Revenue per Worker & $-0.029^{* * *}$ & & $0.028^{* *}$ & & 0.005 \\
& $(0.011)$ & & $(0.012)$ & & $(0.006)$ & \\
Revenue per Hour & & $-0.039^{* * *}$ & & $0.037^{* * *}$ & & 0.007 \\
& & $(0.012)$ & & $(0.013)$ & & $(0.007)$ \\
Number of Owners & $0.039^{* * *}$ & $0.039^{* * *}$ & $-0.030^{* * *}$ & $-0.030^{* * *}$ & $-0.007^{* * *}$ & $-0.007^{* * *}$ \\
& $(0.005)$ & $(0.005)$ & $(0.004)$ & $(0.004)$ & $(0.002)$ & $(0.002)$ \\
\hline Mean Y & 0.431 & 0.431 & 0.509 & 0.509 & 0.056 & 0.056 \\
Observations & 2,524 & 2,524 & 2,524 & 2,524 & 2,524 & 2,524 \\
R-squared & 0.122 & 0.124 & 0.107 & 0.108 & 0.024 & 0.024 \\
\hline
\end{tabular}

Note: Table 4 reports results from regressing indicators for West German, International, and East German majority firm ownership on log initial (pre-privatization) productivity with survey-time FE, industry FE (3-digit), and state FE. Ownership indicators measure whether a majority of owners were based in the respective geography in 1995. The sample encompasses only privatized firms. Robust standard errors in parentheses. ${ }^{* * *} \mathrm{p}<0.01{ }^{* *} \mathrm{p}<0.05 * \mathrm{p}<0.1$

Sources: BvS Firm Register, Treuhand Firm Surveys, and MUP Firm Register.

We test the robustness of our findings by employing a number of alternative specifications, documented in Tables A.8, A.9 and A.10 of the Appendix. Our results remain fundamentally unchanged when using district instead of state-level fixed effects, when using 4-digit instead of 3-digit industry codes, and when using gross value added as an alternative measure of pre-privatization productivity. When limiting the sample of firms analyzed to the manufacturing sector, our results become slightly less significant.

In summary, we observe that West Germans own a substantial share of formerly state-owned firms in East Germany, especially larger and a priori more productive firms. Several factors could explain why the Treuhand may have favored selling firms to West German investors. First, the degree to which potential investors have access to financial capital may vary substantially between Eastern Germany, Western Germany, and other countries. Unlike East German investors, West German and international investors were probably able to build on existing connections to financial institutions. It is also likely that they were able to use existing property as collateral. Therefore, they had advantages in accessing capital to invest in the larger and more attractive Treuhand firms. Second, West German investors may have had access to better market knowledge. Thus, they may have been able to better gauge the productivity of firms and to predict which may have more value going forward. Third, West German investors may have had better access to political connections, enabling them to gain access to the most productive firms on offer. Ex-ante familiarity with post-reunification institutions in the mold of their West German predecessors may have put West German investors at an advantage vis-a-vis East German investors who were learning to build 
networks in an unfamiliar political system. While we cannot differentiate between these factors, data limitations notably imply that this picture of the ownership distribution likely constitutes a lower bound for the degree of West German and international firm ownership in East Germany following the Treuhand program.

5.4. Long-Term Survival of Privatized Firms. In this section, we investigate the short- and long-term survival rates of privatized firms. As privatization schemes intend state-owned firms to become a thriving part of the private sector, firm survival is an important condition for firm performance and privatization success. For large-scale privatization programs, survival is an additional key policy concern when trying to maintain sufficient levels of economic activity in the regions where privatizations take place. Accordingly, the main ambitions of the Treuhand included ensuring the provision of employment opportunities and enabling the East German economy to catch up with the West. The success of privatized firms was crucial to these objectives as firm closures would be associated with substantial increases in regional unemployment and might curtail further economic activity.

Survival is also closely linked to ownership. In the previous section, we find that West German ownership of privatized firms increases with firms' productivity. Previous surveys on privatizations in transition economies find a positive relationship between foreign ownership and firm performance (Megginson and Netter, 2001; Estrin, Hanousek, Kočenda, and Svejnar, 2009). For a number of reasons, there is no a priori consensus on whether we would find a similar relationship between ownership and survival in the Treuhand case. While, on average, West German investors had considerably more experience managing firms in a competitive market-based economy than their East German counterparts. As such, they may have been better suited to run a market-oriented firm in a profitable way, resulting in higher survival rates. Privatization literature has discussed the importance of such human capital advantages for privatization success (Barberis, Boycko, Shleifer, and Tsukanova, 1996). On the other hand, we have already shown that firms that are more efficient had an increased chance of ending up in West German ownership. Assuming that past efficiency can reasonably predict future efficiency, these firms may have been of higher quality to begin with. Thus, we would expect that these firms were also inherently more likely to survive. Therefore, superior performance of firms owned by West German investors may derive from selection effects. That said, the very ability to select the right firms for acquisition might be a key part of the West German managers' skill and experience set. In addition, anecdotal evidence suggests that West German owners, and in particular corporate owners, attempted to use the privatization scheme to rid themselves of potential competitors. Preemption of competitive pressures can serve as an 
incentive to acquire future rivals with the intention of discontinuing their operations (Cunningham, Ederer, and Ma, 2020). If this behavior was pervasive in East Germany, we could in fact expect Western ownership to be negatively associated with firm survival.

Figure 9. Survival by Initial Productivity (Privatized Firms)
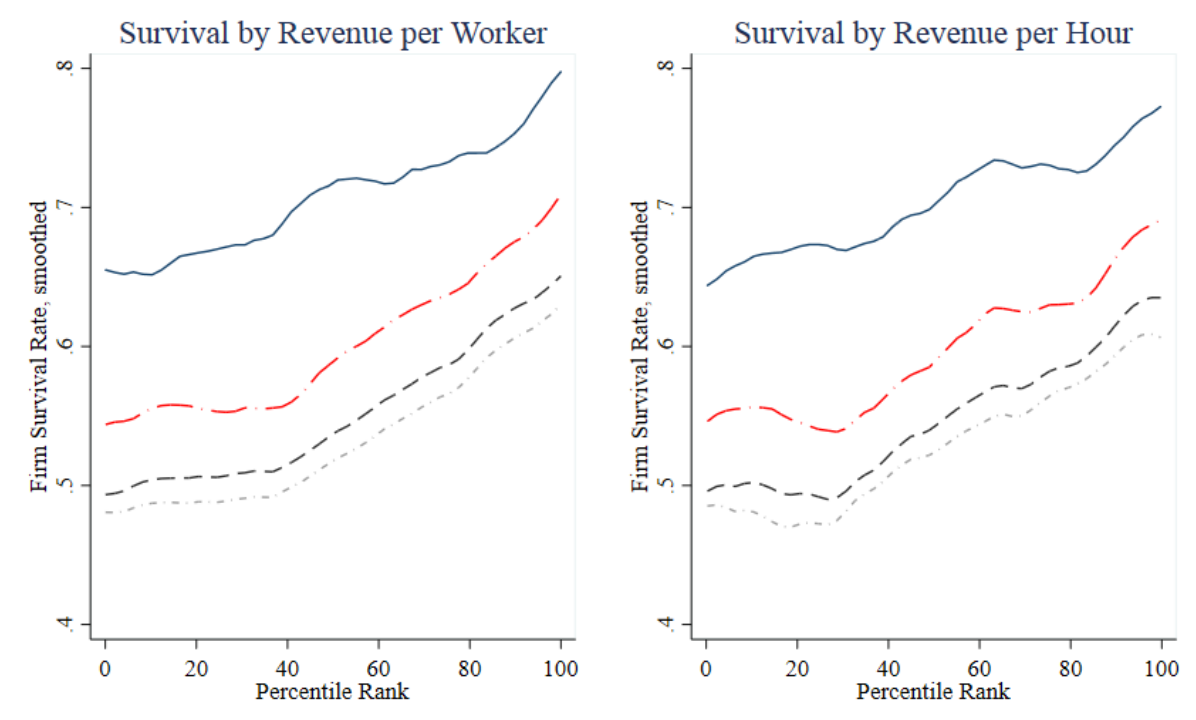

$\longrightarrow$ 5y Survival —- 10y Survival - - - 15y Survival -.... 20y Survival

Note: Survival rates calculated as the percentage of firms still active 5, 10, 15, and 20 years after the dissolution of the Treuhandanstalt. Rank coefficients calculated using Hazen's rule. Smoothing procedure uses an Epanechnikov kernel function of degree zero. N = 2,524.

Sources: BvS Firm Register, Treuhand Firm Surveys, and MUP Firm Register.

We begin by graphically analyzing survival rates. Figure 9 displays survival rates over time. Five-, ten-, fifteen- and twenty-year survival rates are plotted against the respective firms' percentile rank of initial productivity. The panel on the left depicts post-Treuhand survival across the distribution of labor productivity, while the panel on the right depicts the same series against revenue per hour worked. While there are notable level shifts in survival rates affecting the entire productivity distribution, we can generally see a similar trend across all indicators. Firms that are more productive are more likely to survive and continue operations. Nonetheless, we observe a considerable amount of attrition in the set of privatized firms on aggregate. Even among the most productive firms, almost four in ten businesses are no longer operating after fifteen or twenty years.

We focus on the relationship between ownership and survival in Table 5. We use ordinary least squares regressions of survival indicators to assess the correlation between specific ownership types and survival rates depending on initial firm productivity. We do not find a significant association 
of West German majority ownership and five-year survival rates for privatized firms. However, West German ownership predicts higher survival rates over the ten, 15, and 20 year time frames. These point estimates are increasing as the time horizon widens. For all time frames, we find that initially more productive firms have greater rates of survival. Table ?? in the appendix confirms these results for using revenue per hour as our measure of productivity.

Table 5. Majority Ownership, Initial Revenue per Worker and Firm Survival

\begin{tabular}{lcccc}
\hline & 5y Survival & 10y Survival & 15y Survival & 20y Survival \\
& $(1)$ & $(2)$ & $(3)$ & $(4)$ \\
\hline Majority West Ownership & 0.022 & $0.037^{*}$ & $0.062^{* * *}$ & $0.066^{* * *}$ \\
& $(0.020)$ & $(0.021)$ & $(0.022)$ & $(0.022)$ \\
Int'l Ownership & 0.006 & 0.052 & 0.058 & 0.050 \\
& $(0.037)$ & $(0.040)$ & $(0.041)$ & $(0.041)$ \\
Majority West \& Int'l Ownership & -0.053 & -0.031 & -0.080 & -0.065 \\
& $(0.064)$ & $(0.069)$ & $(0.070)$ & $(0.070)$ \\
Number of Owners & $0.012^{* * *}$ & 0.007 & 0.003 & 0.004 \\
Initial Revenue per Worker & $(0.004)$ & $(0.005)$ & $(0.005)$ & $(0.005)$ \\
& $0.029^{* * *}$ & $0.049^{* * *}$ & $0.045^{* * *}$ & $0.045^{* * *}$ \\
& $(0.010)$ & $(0.011)$ & $(0.011)$ & $(0.011)$ \\
\hline Mean Y & 0.704 & 0.597 & 0.547 & 0.528 \\
Rbservations & 2,524 & 2,524 & 2,524 & 2,524 \\
R-squared & 0.048 & 0.060 & 0.060 & 0.059 \\
\hline
\end{tabular}

Note: Table 5 reports results from regressing indicators for $5,10,15$, and 20-year survival of privatized firms on majority ownership indicators, log initial (pre-privatization) productivity, and additional controls with survey-time FE, industry FE (3-digit), and state FE. Ownership indicators measure whether a majority of owners was based in the respective geography in 1995. The sample encompasses only privatized firms. Robust standard errors are in parentheses. ${ }^{* * *} \mathrm{p}<0.01 * * \mathrm{p}<0.05 * \mathrm{p}<0.1$

These findings entail several implications. The positive correlation between ownership from West Germany and survival seemingly contradicts the popular narrative suggesting that West German owners brought about large-scale closure of potentially viable firms. Generally, this finding is consistent with prior findings in the privatization literature that documents the benefits of foreign ownership of privatized firms (Estrin, Hanousek, Kočenda, and Svejnar, 2009). One explanation for the higher survival rates of firms with West German majority ownership may be the differences in market knowledge or managers' human capital (Rosen, 1992; Barberis, Boycko, Shleifer, and Tsukanova, 1996). However, survival also appears to be closely linked to initial firm productivity. Therefore, it is possible that the superior survival rates of West German owners are to some extent explained by West German investors' preferential access to the most productive firms. The finding that productivity is an important driver of long-term firm survival after privatization also corroborates the importance of the privatization agency's screening function for successful privatization programs. By its construction, survival is a lagging indicator of firm success as, for instance, deregistration from the trade register only takes effect sometime after a firm has ceased 
to operate. Therefore, the analysis of survival rates may overestimate the number of firms still operating at a given point in time.

\section{Discussion and Conclusion}

This paper provides the first comprehensive analysis of East Germany's mass privatization program, arguably history's most radical privatization package. By combining firm surveys with archival and administrative microdata, we are able to trace large subsets of firms from the end of the privatization process until two decades later. Adopting this long-term view of the privatization program and its consequences allows us to investigate the much-debated reshaping of the East German economy. Our results reveal that firms that are initially more productive were increasingly likely to be privatized, privatized faster, and sold at higher prices. We also document that the Treuhand assigned higher firm quality ratings to firms that are more productive. In addition to documenting the privatization process, we study short- and long-term privatization outcomes. We find that firms that are more productive were increasingly likely to be privatized to non-local owners, especially from West Germany. Firms that are more productive also display higher survival rates. Over a time horizon of ten years or more, we show that firms sold to new owners from West Germany have higher survival rates even after conditioning on baseline productivity. In summary, it is possible to interpret these findings as being in line with the Treuhand's legal mandate.

Assessing whether the Treuhand policy was optimal goes beyond the scope of our study. This is because economic theory suggests both positive and negative welfare implications of our findings. On the positive side, the closure of less productive state-owned enterprises increased aggregate labor productivity in the Treuhand-held firm stock. Therefore, goods can be produced at cheaper costs such that in competitive markets lower prices may be passed on to consumers. Moreover, labor in unproductive firms is freed and can be reallocated to firms with higher productivity and possibly higher wages (Melitz, 2003). On the downside, firm closures can lead to a direct squeeze of output, employment, and income. Castanheira and Roland (2000) argue that unproductive firms in East Germany may have been closed too quickly. The ensuing output contraction could have depressed savings needed to finance private investment. From a general equilibrium perspective, temporary unemployment and search frictions can deepen regional economic downturns (Chodorow-Reich and Wieland, 2020). In addition, company closures dilute the geographic clustering of firms, thereby reducing agglomeration spillovers (Greenstone, Hornbeck, and Moretti, 2010). Our analysis cannot differentiate the individual importance of these arguments. 


\section{References}

Acemoglu, D., U. Akcigit, H. Alp, N. Bloom, and W. Kerr (2018): "Innovation, Reallocation, and Growth," American Economic Review, 108(11), 3450-91.

Acemoglu, D., S. Naidu, P. Restrepo, and J. A. Robinson (2015): "Democracy, redistribution, and inequality," in Handbook of Income Distribution, vol. 2, pp. 1885-1966. Elsevier.

AdLer, S. (2019): "Alle gegen die Treuhand," Deutschlandfunk Kultur, 2019-10-22.

Akerlof, G. A., A. K. Rose, J. L. Yellen, and H. Hessenius (1991): "East Germany in from the Cold: The Economic Aftermath of Currency Union," Brookings Papers on Economic Activity, 22(1), 1-106.

Alesina, A., And D. Rodrik (1994): "Distributive Politics and Economic Growth," The Quarterly Journal of Economics, 109(2), 465-490.

Barberis, N., M. Boycko, A. Shleifer, and N. Tsukanova (1996): "How Does Privatization Work? Evidence from the Russian Shops," Journal of Political Economy, 104(4), 764-790.

Bersch, J., S. Gottschalk, B. Mueller, and M. Niefert (2014): "The Mannheim Enterprise Panel (MUP) and Firm Statistics for Germany," Discussion paper, ZEW - Centre For European Economic Research Mannheim.

BöICK, M. (2018): Die Treuhand: Idee - Praxis - Erfahrung 1990-1994. Wallstein Verlag.

Bollinger, C. R., And A. Chandra (2005): "Iatrogenic specification error: A cautionary tale of cleaning data," Journal of Labor Economics, 23(2), 235-257.

Bolton, P., And G. Roland (1992): "Privatization policies in central and eastern Europe," Economic Policy, 7(15), 275-309.

Boycko, M., A. Shleifer, and R. W. Vishny (1996): "A theory of privatisation," The Economic Journal, 106(435), 309-319.

Brown, J. D., J. S. Earle, And A. Telegdy (2006): "The Productivity Effects of Privatization: Longitudinal Estimates from Hungary, Romania, Russia, and Ukraine," Journal of Political Economy, 114(1), 61-99.

(2010): "Employment and Wage Effects of Privatisation: Evidence from Hungary, Romania, Russia and Ukraine," The Economic Journal, 120(545), 683-708.

Bundesanstalt für Vereinigungsbedingte Sonderaufgaben (1994): "Abschlussstatistik der Treuhandanstalt per 31.12.1994," Brochure, BvS Berlin.

(2003): "Schnell privatisieren, entschlossen sanieren, behutsam stilllegen": ein Rückblick auf 13 Jahre Arbeit der Treuhandanstalt und der Bundesanstalt für Vereinigungsbedingte Sonderaufgaben. Wegweiser Verlag, Berlin.

- (2016): "Firm Register," data sheet obtained from BvS Berlin.

Bundesarchiv (2019): "Leitungsausschuss - Sitzungsprotokolle mit Vorlagen," BArch B 412/16257, et seqq., Berlin-Lichterfelde.

Carlin, W., And C. MAyer (1994): "The Treuhandanstalt: Privatization by state and market," in The Transition in Eastern Europe, Volume 2: Restructuring, ed. by O. Blanchard, K. Froot, and J. Sachs, pp. 189-214. University of Chicago Press.

Castanheira, M., and G. Roland (2000): "The Optimal Speed of Transition: A General Equilibrium Analysis," International Economic Review, 41(1), 219-239.

Chodorow-Reich, G., and J. Wieland (2020): "Secular Labor Reallocation and Business Cycles," Journal of Political Economy, 128(6), 2245-2287.

Clarke, G. R., AND L. C. XU (2004): "Privatization, competition, and corruption: how characteristics of bribe takers and payers affect bribes to utilities," Journal of Public Economics, 88(9), 2067-2097.

Cunningham, C., F. Ederer, and S. Ma (2020): "Killer acquisitions," Journal of Political Economy (forthcoming).

Decker, R. A., J. Haltiwanger, R. S. Jarmin, and J. Miranda (2017): "Declining dynamism, allocative efficiency, and the productivity slowdown," American Economic Review, 107(5), 322-26.

Deutscher Bundestag (1994): "Beschlussempfehlung und Bericht des 2. Untersuchungsausschusses "Treuhandanstal" nach Artikel 44 des Grundgesetzes," Drucksache 12/8404.

Dinc, I. S., And N. Gupta (2011): "The decision to privatize: Finance and politics," The Journal of Finance, 66(1), 241-269. 
Djankov, S., And P. Murrell (2002): "Enterprise Restructuring in Transition: A Quantitative Survey," Journal of Economic Literature, 40(3), 739-792.

Dornbusch, R., And H. C. Wolf (1994): "East German Economic Reconstruction," in The Transition in Eastern Europe, Volume 1, pp. 155-190. University of Chicago Press.

Dorsch, M. T., And P. MAAREK (2019): "Democratization and the Conditional Dynamics of Income Distribution," American Political Science Review, 113(2), 385-404.

Dyck, A. (1997): "Privatization in Eastern Germany: Management Selection and Economic Transition," American Economic Review, 87(4), 565-97.

Estrin, S., J. Hanousek, E. KoČEnda, And J. Svejnar (2009): "The effects of privatization and ownership in transition economies," Journal of Economic Literature, 47(3), 699-728.

Faccio, M., R. W. Masulis, and J. J. McConnell (2006): "Political Connections and Corporate Bailouts," The Journal of Finance, 61(6), 2597-2635.

Frydman, R., C. Gray, M. Hessel, and A. Rapaczynski (1999): "When Does Privatization Work? The Impact of Private Ownership on Corporate Performance in the Transition Economies," The Quarterly Journal of Economics, 114(4), 1153-1191.

Gan, J., Y. Guo, And C. Xu (2018): "Decentralized Privatization and Change of Control Rights in China," The Review of Financial Studies, 31(10), 3854-3894.

Greenstone, M., R. Hornbeck, And E. Moretti (2010): "Identifying Agglomeration Spillovers: Evidence from Winners and Losers of Large Plant Openings," Journal of Political Economy, 118(3), 536-598.

Grossman, G. M., And E. Helpman (1996): "Electoral competition and special interest politics," The Review of Economic Studies, 63(2), 265-286.

Gupta, N., J. C. Ham, And J. Svejnar (2008): "Priorities and sequencing in privatization: Evidence from Czech firm panel data," European Economic Review, 52(2), 183-208.

Guriev, S., and A. Rachinsky (2005): "The role of oligarchs in Russian capitalism," Journal of Economic Perspectives, 19(1), 131-150.

Haltiwanger, J. C., H. R. Hyatt, L. B. Kahn, and E. McEntarfer (2018): "Cyclical job ladders by firm size and firm wage," American Economic Journal: Macroeconomics, 10(2), 52-85.

HaU, H. (1998): "Privatization under political interference: Evidence from Eastern Germany," European Economic Review, 42(7), 1177-1201.

Herdegen, G. (1992): "Einstellungen zur deutschen Einheit," in Handwörterbuch zur deutschen Einheit, pp. 272-83.

Hodler, R., ANd P. A. RAschKy (2014): "Regional favoritism," The Quarterly Journal of Economics, 129(2), 995-1033.

KüHL, J., R. Schaefer, And J. WAhse (1991): "Beschäftigungsperspektiven von Treuhandunternehmen," Mitteilungen aus der Arbeitsmarkt- und Berufsforschung, 3, 91.

La Porta, R., F. Lopez-De-Silanes, and A. Shleifer (1999): "Corporate Ownership Around the World," The Journal of Finance, 54(2), 471-517.

LAFFont, J.-J., And J. Tirole (1991): "Privatization and incentives," Journal of Law, Economics, E Organization, 7, 84.

LAmparter, D. H. (1992): “Zurück zum Staat?," DIE ZEIT, (7).

LopeZ-DE Silanes, F. (1997): "Determinants of Privatization Prices," The Quarterly Journal of Economics, 112(4), 965-1025.

MDR (2020): "Die Treuhand wirkt bis heute nach," mdrFRAGT, 2020-03-03.

Megrinson, W. L. (2017): "Privatization Trends and Major Deals in 2015 and 2016," in The PB Report 2015/2016. The Privatization Barometer.

Megginson, W. L., And J. M. Netter (2001): "From state to market: A survey of empirical studies on privatization," Journal of Economic Literature, 39(2), 321-389.

Melitz, M. J. (2003): "The impact of trade on intra-industry reallocations and aggregate industry productivity," Econometrica, 71(6), 1695-1725.

Milanovic, B., And L. ERsado (2012): "Reform and inequality during the transition: an analysis using panel household survey data, 1990-2005," in Economies in Transition, pp. 84-108. Springer.

Novokmet, F., T. Piketty, L. Yang, and G. Zucman (2018): "From communism to capitalism: private versus public property and inequality in China and Russia," in AEA Papers and Proceedings, vol. 108, pp. 109-13.

OECD (2015): "Main Economic Indicators - complete database," DOI: 10.1787/data-00052-en. 
Orban, K. (2019): "The Inception of Capitalism through the Lens of Firms," mimeo.

Piketry, T. (2014): Capital in the 21st Century. Harvard University Press Cambridge, MA. 48-53.

Puruu, A. (1996): "Political Economy of Privatisation in Estonia," CERT Discussion Papers 9602, Centre for Economic Reform and Transformation, Heriot Watt University.

Renken, K., And W. Jenke (2001): "Wirtschaftskriminalität im Einigungsprozess," Aus Politk und Zeitgeschichte, B 32-33.

Roland, G. (1994): "On the Speed and Sequencing of Privatisation and Restructuring," The Economic Journal, 104(426), 1158-1168.

Rosen, S. (1992): "Contracts and the Market for Executives," in Contract Economics. Blackwell. Shleifer, A., And R. W. Vishny (1994): "Politicians and firms," The Quarterly Journal of Economics, 109(4), 995-1025.

SyVERSON, C. (2011): "What determines productivity?," Journal of Economic Literature, 49(2), $326-65$.

Treuhandanstalt (1994): Treuhandanstalt: Dokumentation 1990 - 1994.

vON LieBen, M. (2019): "Wahlkampf mit der Treuhand," Deutschlandfunk, 2019-06-06. 


\section{Appendix A. Supplementary Graphs and Tables}

\section{Descriptive Statistics}

Table A.1. Descriptive Statistics

\begin{tabular}{lcccccc}
\hline & Mean & Std. Dev & Min & Max & Count & Source \\
\hline Privatization Outcomes & & & & & & \\
Privatization Indicator & & & & & & \\
Months to Privatization since July 1990 & 25.97 & 14.26 & 0.00 & 53.00 & 3957 & THA \\
Privatization Price (in 1000 DM) & 2666.48 & 11556.52 & 0.00 & 376203.42 & 2145 & THA \\
Employment Pledge & 130.88 & 315.83 & 0.00 & 6500.00 & 2145 & THA \\
Investment Pledge (in 1000 DM) & 8506.29 & 29096.92 & 0.00 & 530000.00 & 2145 & THA \\
Majority Ownership East (1/0) & 0.43 & 0.50 & 0.00 & 1.00 & 2524 & MUP \\
Majority Ownership West (1/0) & 0.51 & 0.50 & 0.00 & 1.00 & 2524 & MUP \\
Majority Ownership Int'l (1/0) & 0.06 & 0.23 & 0.00 & 1.00 & 2524 & MUP \\
5 Year Post-THA Survival (1/0) & 0.70 & 0.46 & 0.00 & 1.00 & 2524 & MUP \\
10 Year Post-THA Survival (1/0) & 0.60 & 0.49 & 0.00 & 1.00 & 2524 & MUP \\
15 Year Post-THA Survival (1/0) & 0.55 & 0.50 & 0.00 & 1.00 & 2524 & MUP \\
20 Year Post-THA Survival (1/0) & 0.53 & 0.50 & 0.00 & 1.00 & 2524 & MUP \\
& & & & & & \\
Firm Characteristics & & & & & & \\
Number of Employees & 362.61 & 680.33 & 0.00 & 5308.00 & 6015 & SÖSTRA \\
Revenue (in 1000 DM) & 24239.22 & 88966.01 & 0.00 & 3824609.50 & 6015 & SÖSTRA \\
Log Annual Revenue per Worker (in DM) & 4.29 & 1.05 & 0.44 & 7.95 & 6015 & SÖSTRA \\
Log Revenue per Hour Worked (in DM) & 3.75 & 0.97 & 0.13 & 7.22 & 6015 & SÖSTRA \\
Log Gross Value Added p.a. (in 1000 DM) & 7.86 & 1.78 & 1.89 & 12.52 & 3162 & SÖSTRA \\
\hline
\end{tabular}

Sources.- BvS Firm Register, THA Firm Surveys, THA Firm Ratings, THA Contract Data, MUP Firm Register. 


\section{Sensitivity Analysis}

Table A.2. Regression Results: Privatization - Alternative Specifications

Outcome Variable: Privatization Indicator

(1)

\begin{tabular}{ccc}
\hline Log Revenue per Worker & $0.079^{* * *}$ & $0.095^{* * *}$ \\
$(0.007)$ & $(0.009)$
\end{tabular}

Log Gross Value Added

$(0.009)$

(3)

$(4)$

$\begin{array}{ccc}0.076^{* * *} & 0.078^{* * *} & 0.082^{* * *} \\ (0.007) & (0.007) & (0.007)\end{array}$

$(0.004)$

\begin{tabular}{lcccccc}
\hline Mean Y & 0.68 & 0.68 & 0.82 & 0.66 & 0.68 & 0.68 \\
Geo-FE & State & State & State & Local & District & State \\
& & & & Branch & & \\
Industry-FE & 3-digits & 3-digits & 3-digits & 3-digits & 3-digits & 4-digits \\
Sample & Manuf. & Manuf. & Manuf. & Manuf. & Manuf. & Manuf. \\
& + Serv. & & + Serv. & + Serv. & + Serv. & + Serv. \\
Observations & 6,015 & 3,963 & 3,148 & 5,674 & 6,014 & 6,047 \\
\hline
\end{tabular}

Notes. ${ }^{*} p<0.1 ; * * p<0.05 ; * * * p<0.01$. Each column presents a different estimation of equation (1). Column (1) controls for three firm employment size dummies. Column (2) restricts the sample to manufacturing only. Column (3) uses alternative productivity measure log gross value added. Column (4) has 15 local Treuhand branch +1 headquarter fixed-effects. Column (5) uses district fixed-effects. Column (6) has more narrow 4-digit industry fixed-effects. The outcome variable is a dummy equaling 1 if a firm was privatized at the end of 1994 and 0 otherwise. Robust standard errors given in parentheses.

Sources.- BvS Firm Register and THA Firm Surveys.

Table A.3. Regression Results: Time to Privatization - Alternative Specifications

Outcome Variable: Months under THA ownership

(1)

(2)

(3)

(4)

$(5)$

(6)

\begin{tabular}{cccccc}
\hline Log Revenue per Worker & - & - & - & - & - \\
& $1.276^{* * *}$ & $1.688^{* * *}$ & $1.404^{* * *}$ & $1.374^{* * *}$ & $1.152^{* * *}$ \\
& $(0.271)$ & $(0.356)$ & $(0.291)$ & $(0.281)$ & $(0.288)$
\end{tabular}

Log Gross Value Added

$-$

$1.142^{* * *}$

$(0.192)$

\begin{tabular}{lcccccc}
\hline Mean Y & 25.97 & 24.68 & 26.01 & 25.91 & 25.96 & 26.00 \\
Geo-FE & State & State & State & Local & District & State \\
& & & & Branch & & \\
Industry-FE & 3-digits & 3-digits & 3-digits & 3-digits & 3-digits & 4-digits \\
Sample & Manuf. & Manuf. & Manuf. & Manuf. & Manuf. & Manuf. \\
& + Serv. & & + Serv. & + Serv. & + Serv. & + Serv. \\
Observations & 3,957 & 2,645 & 2,536 & 3,694 & 3,956 & 3,974 \\
\hline
\end{tabular}

Notes. ${ }^{*} p<0.1 ;{ }^{*} p<0.05 ;{ }^{* * *} p<0.01$. Each column presents a different estimation of equation (1). Column (1) controls for three firm employment size dummies. Column (2) restricts the sample to manufacturing only. Column (3) uses alternative productivity measure log gross value added. Column (4) has 15 local Treuhand branch +1 headquarter fixed-effects. Column (5) uses district fixed-effects. Column (6) has more narrow 4-digit industry fixed-effects. The outcome variable is the number of months until privatization since July 1990. Robust standard errors given in parentheses.

Sources.- BvS Firm Register and THA Firm Surveys. 
Table A.4. Regression Results: Privatization, Time to Privatization and Productivity at the VEB-level

\begin{tabular}{lcccc}
\hline & $(1)$ & $(2)$ & $(3)$ & $(4)$ \\
& Mean Privatization Probability & $\begin{array}{c}\text { Mean Months to Privatization } \\
\text { Log Revenue per Worker }\end{array}$ & $\begin{array}{c}0.070^{* * *} \\
(0.009)\end{array}$ & $\begin{array}{c}-1.612^{* * *} \\
(0.362)\end{array}$ \\
Log Revenue per Hour & & $0.066^{* * *}$ & & $-2.021^{* * *}$ \\
& & $(0.009)$ & & $(0.372)$ \\
\hline Mean Y & 0.64 & 0.64 & 26.40 & 26.40 \\
R-squared & 0.106 & 0.103 & 0.306 & 0.310 \\
Observations & 4,070 & 4,070 & 2,496 & 2,496 \\
\hline
\end{tabular}

Notes.- Each column presents an OLS regression at the level of Volkseigene Betriebe (VEB) with industry FE (3-digit), state FE, and survey-time FE. We aggregate Treuhand firms to VEBs by averaging outcomes and productivity levels and using modes for fixed-effect variables. The outcome variable for columns (1) and (2) is the share of firms belonging to a given VEB that was privatized at the end of 1994. For column (3) and (4) the outcome is the average number of months until privatization. The sample excludes firms indicated as spin-offs that cannot directly be linked to a former VEB. Robust standard errors given in parentheses. ${ }^{*} p<0.1 ; * *<0.05 ;{ }^{* * *} p<0.01$.

Sources.- BvS Firm Register and THA Firm Surveys.

Table A.5. Regression Results: Sales Prices in Privatization Contracts - Alternative Specifications

\begin{tabular}{|c|c|c|c|c|c|c|}
\hline & \multicolumn{6}{|c|}{ Outcome Variable: Log Price } \\
\hline & (1) & $(2)$ & $(3)$ & $(4)$ & $(5)$ & $(6)$ \\
\hline Log Revenue per Worker & $\begin{array}{c}0.338^{* * *} \\
(0.089)\end{array}$ & $\begin{array}{c}0.354^{* * *} \\
(0.093)\end{array}$ & & $\begin{array}{c}0.341^{* * *} \\
(0.090)\end{array}$ & $\begin{array}{c}0.309^{* * *} \\
(0.089)\end{array}$ & $\begin{array}{c}0.331^{* * *} \\
(0.104)\end{array}$ \\
\hline Log Gross Value Added & & & $\begin{array}{c}0.645^{* * *} \\
(0.063)\end{array}$ & & & \\
\hline Mean Y & 13.17 & 13.16 & 13.14 & 13.14 & 13.17 & 13.16 \\
\hline Firm Size & $\checkmark$ & & & & & \\
\hline Geo-FE & State & State & State & $\begin{array}{c}\text { Local } \\
\text { Branch }\end{array}$ & District & State \\
\hline Industry-FE & 3-digits & 3-digits & 3-digits & 3-digits & 3-digits & 4-digits \\
\hline Sample & $\begin{array}{l}\text { Manuf. } \\
+ \text { Serv. }\end{array}$ & Manuf. & $\begin{array}{l}\text { Manuf. } \\
+ \text { Serv. }\end{array}$ & $\begin{array}{l}\text { Manuf. } \\
+ \text { Serv. }\end{array}$ & $\begin{array}{l}\text { Manuf. } \\
+ \text { Serv. }\end{array}$ & $\begin{array}{l}\text { Manuf. } \\
+ \text { Serv. }\end{array}$ \\
\hline Observations & 1,494 & 1,482 & 980 & 1,443 & 1,494 & 1,497 \\
\hline
\end{tabular}

Notes. ${ }^{*} p<0.1 ; * * p<0.05 ; * * * p<0.01$. Each column presents a different estimation of equation (1). Column (1) controls for three firm employment size dummies. Column (2) restricts the sample to manufacturing only. Column (3) uses alternative productivity measure log gross value added. Column (4) has 15 local Treuhand branch +1 headquarter fixed-effects. Column (5) uses district fixed-effects. Column (6) has more narrow 4-digit industry fixed-effects. As missing values are indistinguishable from 0's in Hau's contract data, the columns report average marginal effects from left-0-truncated regression models. Positive values are log-transformed. The outcome variable is sales price. Positive values are log-transformed. Robust standard errors given in parentheses.

Sources.- THA Contract Data and THA Firm Surveys. 
Table A.6. Regression Results: Employment Pledge in Privatization Contracts - Alternative Specifications

\begin{tabular}{|c|c|c|c|c|c|c|}
\hline & \multicolumn{6}{|c|}{ Outcome Variable: Log Employment Pledge } \\
\hline & (1) & $(2)$ & $(3)$ & $(4)$ & $(5)$ & $(6)$ \\
\hline Log Revenue per Worker & $\begin{array}{c}0.122^{* * *} \\
(0.040)\end{array}$ & $\begin{array}{c}0.119^{* * *} \\
(0.046)\end{array}$ & & $\begin{array}{c}0.098^{* *} \\
(0.039)\end{array}$ & $\begin{array}{c}0.130^{* * *} \\
(0.044)\end{array}$ & $\begin{array}{c}0.173^{* * *} \\
(0.052)\end{array}$ \\
\hline Log Gross Value Added & & & $\begin{array}{c}0.597^{* * *} \\
(0.032)\end{array}$ & & & \\
\hline Mean Y & 4.24 & 4.24 & 4.31 & 4.23 & 4.24 & 4.24 \\
\hline Firm Size & $\checkmark$ & & & & & \\
\hline Geo-FE & State & State & State & $\begin{array}{c}\text { Local } \\
\text { Branch }\end{array}$ & District & State \\
\hline Industry-FE & 3-digits & 3-digits & 3-digits & 3-digits & 3-digits & 4-digits \\
\hline Sample & $\begin{array}{l}\text { Manuf. } \\
+ \text { Serv. }\end{array}$ & Manuf. & $\begin{array}{l}\text { Manuf. } \\
+ \text { Serv. }\end{array}$ & $\begin{array}{l}\text { Manuf. } \\
+ \text { Serv. }\end{array}$ & $\begin{array}{l}\text { Manuf. } \\
+ \text { Serv. }\end{array}$ & $\begin{array}{l}\text { Manuf. } \\
+ \text { Serv. }\end{array}$ \\
\hline Observations & 1,627 & 1,614 & 1,048 & 1,586 & 1,627 & 1,629 \\
\hline
\end{tabular}

Notes. $^{*} p<0.1 ; * * p<0.05 ;{ }^{* * *} p<0.01$. Each column presents a different estimation of equation (1). Column (1) controls for three firm employment size dummies. Column (2) restricts the sample to manufacturing only. Column (3) uses alternative productivity measure log gross value added. Column (4) has 15 local Treuhand branch +1 headquarter fixed-effects. Column (5) uses district fixed-effects. Column (6) has more narrow 4-digit industry fixed-effects. As missing values are indistinguishable from 0's in Hau's contract data, the columns report average marginal effects from left-0-truncated regression models. Positive values are log-transformed. The outcome variable is employment guarantees. Positive values are log-transformed. Robust standard errors given in parentheses.

Sources.- THA Contract Data and THA Firm Surveys.

Table A.7. Regression Results: Investment Pledge in Privatization Contracts - Alternative Specifications

\begin{tabular}{|c|c|c|c|c|c|c|}
\hline & \multicolumn{6}{|c|}{ Outcome Variable: Log Investement Pledge } \\
\hline & $(1)$ & $(2)$ & $(3)$ & $(4)$ & $(5)$ & $(6)$ \\
\hline Log Revenue per Worker & $\begin{array}{c}0.161^{* * *} \\
(0.050)\end{array}$ & $\begin{array}{c}0.162^{* * *} \\
(0.059)\end{array}$ & & $\begin{array}{c}0.127^{* *} \\
(0.052)\end{array}$ & $\begin{array}{c}0.178^{* * *} \\
(0.056)\end{array}$ & $\begin{array}{r}0.160^{\text {*** }} \\
(0.060)\end{array}$ \\
\hline Log Gross Value Added & & & $\begin{array}{c}0.641^{* * *} \\
(0.041)\end{array}$ & & & \\
\hline Mean Y & 14.81 & 14.81 & 14.89 & 14.79 & 14.81 & 14.81 \\
\hline Firm Size & $\checkmark$ & & & & & \\
\hline Geo-FE & State & State & State & $\begin{array}{c}\text { Local } \\
\text { Branch }\end{array}$ & District & State \\
\hline Industry-FE & 3-digits & 3-digits & 3-digits & 3-digits & 3-digits & 4-digits \\
\hline Sample & Manuf. & Manuf. & Manuf. & Manuf. & Manuf. & Manuf. \\
\hline Observations & $\begin{array}{c}\text { + Serv. } \\
1,548\end{array}$ & 1,536 & $\begin{array}{l}+ \text { Serv. } \\
994\end{array}$ & $\begin{array}{c}+ \text { Serv } \\
1,506\end{array}$ & $\begin{array}{c}+ \text { Serv. } \\
1,548\end{array}$ & $\begin{array}{c}\text { + Serv. } \\
1,550\end{array}$ \\
\hline
\end{tabular}

Notes. ${ }^{*} p<0.1 ;{ }^{* *} p<0.05 ;{ }^{* * *} p<0.01$. Each column presents a different estimation of equation (1). Column (1) controls for three firm employment size dummies. Column (2) restricts the sample to manufacturing only. Column (3) uses alternative productivity measure log gross value added. Column (4) has 15 local Treuhand branch +1 headquarter fixed-effects. Column (5) uses district fixed-effects. Column (6) has more narrow 4-digit industry fixed-effects. As missing values are indistinguishable from 0's in Hau's contract data, the columns report average marginal effects from left-0-truncated regression models. Positive values are log-transformed. The outcome variable is investment guarantees. Positive values are log-transformed. Robust standard errors given in parentheses.

Sources.- THA Contract Data and THA Firm Surveys. 
Table A.8. Regression Results: Majority Ownership East Germany by Initial Productivity Alternative Specifications

\begin{tabular}{|c|c|c|c|c|c|c|}
\hline & \multicolumn{6}{|c|}{ Outcome Variable: Majority Ownership East $(1 / 0)$} \\
\hline & $(1)$ & $(2)$ & $(3)$ & $(4)$ & $(5)$ & $(6)$ \\
\hline Log Revenue per Worker & $\begin{array}{c}-0.035^{* * *} \\
(0.011)\end{array}$ & $\begin{array}{c}-0.021 \\
(0.014)\end{array}$ & & $\begin{array}{c}-0.024^{* *} \\
(0.012)\end{array}$ & $\begin{array}{c}-0.027^{* *} \\
(0.011)\end{array}$ & $\begin{array}{c}-0.033^{* * * *} \\
(0.013)\end{array}$ \\
\hline Log Gross Value Added & & & $\begin{array}{c}-0.070 * * * \\
(0.008)\end{array}$ & & & \\
\hline Mean Y & 0.43 & 0.42 & 0.44 & 0.44 & 0.43 & 0.43 \\
\hline Firm Size & $\checkmark$ & & & & & \\
\hline Geo-FE & State & State & State & $\begin{array}{c}\text { Local } \\
\text { Branch }\end{array}$ & District & State \\
\hline Industry-FE & 3-digits & 3-digits & 3-digits & 3-digits & 3-digits & 4-digits \\
\hline Sample & $\begin{array}{c}\text { Manuf. + } \\
\text { Serv. }\end{array}$ & Manuf. & $\begin{array}{c}\text { Manuf. + } \\
\text { Serv. }\end{array}$ & $\begin{array}{c}\text { Manuf. + } \\
\text { Serv. }\end{array}$ & $\begin{array}{c}\text { Manuf. + } \\
\text { Serv. }\end{array}$ & $\begin{array}{c}\text { Manuf. + } \\
\text { Serv. }\end{array}$ \\
\hline Observations & 2,524 & 1,798 & 1,653 & 2,368 & 2,524 & 2,524 \\
\hline
\end{tabular}

Notes. ${ }^{*} p<0.1 ;{ }^{* *} p<0.05 ;{ }^{* * *} p<0.01$. Each column presents a different estimation of equation (1). Column (1) controls for three firm employment size dummies. Column (2) restricts the sample to manufacturing only. Column (3) uses alternative productivity measure log gross value added. Column (4) has 15 local Treuhand branch +1 headquarter fixed-effects. Column (5) uses district fixed-effects. Column (6) has more narrow 4-digit industry fixed-effects. The outcome variable is an indicator for East majority ownership. Robust standard errors given in parentheses.

Sources.- THA Firm Surveys and MUP Firm Register.

Table A.9. Regression Results: Majority Ownership West Germany by Initial Productivity Alternative Specifications

\begin{tabular}{|c|c|c|c|c|c|c|}
\hline & \multicolumn{6}{|c|}{ Outcome Variable: Majority Ownership West (1/0) } \\
\hline & $(1)$ & $(2)$ & $(3)$ & $(4)$ & $(5)$ & $(6)$ \\
\hline Log Revenue per Worker & $\begin{array}{c}0.033^{* * *} \\
(0.012)\end{array}$ & $\begin{array}{l}0.026^{*} \\
(0.015)\end{array}$ & & $\begin{array}{c}0.024^{* *} \\
(0.012)\end{array}$ & $\begin{array}{c}0.025^{* *} \\
(0.012)\end{array}$ & $\begin{array}{c}0.027^{* *} \\
(0.013)\end{array}$ \\
\hline Log Gross Value Added & & & $\begin{array}{c}0.071^{* * *} \\
(0.008)\end{array}$ & & & \\
\hline Mean Y & 0.51 & 0.52 & 0.49 & 0.50 & 0.51 & 0.51 \\
\hline Firm Size & $\checkmark$ & & & & & \\
\hline Geo-FE & State & State & State & $\begin{array}{c}\text { Local } \\
\text { Branch }\end{array}$ & District & State \\
\hline Industry-FE & 3-digits & 3-digits & 3-digits & 3-digits & 3-digits & 4-digits \\
\hline Sample & $\begin{array}{c}\text { Manuf. + } \\
\text { Serv. }\end{array}$ & Manuf. & $\begin{array}{c}\text { Manuf. + } \\
\text { Serv. }\end{array}$ & $\begin{array}{c}\text { Manuf. + } \\
\text { Serv. }\end{array}$ & $\begin{array}{c}\text { Manuf. + } \\
\text { Serv. }\end{array}$ & $\begin{array}{c}\text { Manuf. + } \\
\text { Serv. }\end{array}$ \\
\hline Observations & 2,524 & 1,798 & 1,653 & 2,368 & 2,524 & 2,524 \\
\hline
\end{tabular}

Notes. ${ }^{*} p<0.1{ }^{* *} p<0.05 ;{ }^{* * *} p<0.01$. Each column presents a different estimation of equation (1). Column (1) controls for three firm employment size dummies. Column (2) restricts the sample to manufacturing only. Column (3) uses alternative productivity measure log gross value added. Column (4) has 15 local Treuhand branch +1 headquarter fixed-effects. Column (5) uses district fixed-effects. Column (6) has more narrow 4-digit industry fixed-effects. The outcome variable is an indicator for West majority ownership. Robust standard errors given in parentheses.

Sources.- THA Firm Surveys and MUP Firm Register. 
Table A.10. Regression Results: Majority Ownership International by Initial Productivity Alternative Specifications

\begin{tabular}{|c|c|c|c|c|c|c|}
\hline & \multicolumn{6}{|c|}{ Outcome Variable: Majority Ownership Int'l (1/0) } \\
\hline & $(1)$ & $(2)$ & (3) & $(4)$ & $(5)$ & $(6)$ \\
\hline Log Revenue per Worker & $\begin{array}{c}0.005 \\
(0.006)\end{array}$ & $\begin{array}{c}-0.001 \\
(0.007)\end{array}$ & & $\begin{array}{c}0.004 \\
(0.006)\end{array}$ & $\begin{array}{c}0.005 \\
(0.006)\end{array}$ & $\begin{array}{c}0.009 \\
(0.006)\end{array}$ \\
\hline Log Gross Value Added & & & $\begin{array}{c}0.002 \\
(0.004)\end{array}$ & & & \\
\hline $\begin{array}{l}\text { Mean Y } \\
\text { Firm Size }\end{array}$ & $\begin{array}{c}0.06 \\
\checkmark\end{array}$ & 0.06 & 0.06 & 0.05 & 0.06 & 0.06 \\
\hline Geo-FE & State & State & State & $\begin{array}{c}\text { Local } \\
\text { Branch }\end{array}$ & District & State \\
\hline Industry-FE & 3-digits & 3-digits & 3-digits & 3-digits & 3-digits & 4-digits \\
\hline $\begin{array}{l}\text { Sample } \\
\text { Observations }\end{array}$ & $\begin{array}{l}\text { Manuf. + } \\
\text { Serv. } \\
2,524\end{array}$ & Manuf. & $\begin{array}{l}\text { Manuf. + } \\
\text { Serv. } \\
1.653\end{array}$ & $\begin{array}{l}\text { Manuf. + } \\
\text { Serv. } \\
2.368\end{array}$ & $\begin{array}{l}\text { Manuf. + } \\
\text { Serv. } \\
2,524\end{array}$ & $\begin{array}{l}\text { Manuf. + } \\
\text { Serv. } \\
2.524\end{array}$ \\
\hline
\end{tabular}

Notes. ${ }^{*} p<0.1 ;{ }^{* *} p<0.05 ;{ }^{* * *} p<0.01$. Each column presents a different estimation of equation (1). Column (1) controls for three firm employment size dummies. Column (2) restricts the sample to manufacturing only. Column (3) uses alternative productivity measure log gross value added. Column (4) has 15 local Treuhand branch +1 headquarter fixed-effects. Column (5) uses district fixed-effects. Column (6) has more narrow 4-digit industry fixed-effects. The outcome variable is an indicator for international majority ownership. Robust standard errors given in parentheses.

Sources.- THA Firm Surveys and MUP Firm Register. 